\title{
66 Years of Corticosteroids in Dentistry: And We Are Still at a Cross Road?
}

\author{
Wei Cheong Ngeow, Daniel Lim and \\ Nurhalim Ahmad \\ Additional information is available at the end of the chapter \\ http://dx.doi.org/10.5772/intechopen.71540
}

\begin{abstract}
Most of the corticosteroids prescribed in dentistry are for topical applications or short-term usage, rarely for its systemic effects or for long-term consumption, as in the treatment of some medical conditions. Among the various specialties in dentistry, oral and maxillofacial surgery, oral medicine and endodontics are the more frequent users of corticosteroids. Corticosteroids are used in oral and maxillofacial procedures to reduce associated post-operative inflammation. The most researched outcome on the use of corticosteroids in oral and maxillofacial surgery revolves around their impact to reduce post-operative pain, swelling and trismus. Topical corticosteroids, on the other hand, are effective in treating various oral mucosal lesions including oral ulcerations and oral presentations of auto-immune diseases. Corticosteroids are also used as part of the treatment of temporomandibular joint disorders. Intracanal placement of corticosteroids is used in endodontic treatment. This chapter reviews the use of corticosteroids in the three specialties of dentistry as mentioned.
\end{abstract}

Keywords: corticosteroids, dentistry, oral and maxillofacial surgery, oral medicine, endodontology

\section{Introduction}

Corticosteroids is one well-known anti-inflammatory group of drugs that is listed in the Dental' Practitioners' Formulary. Among the various specialties in dentistry, oral medicine, oral and maxillofacial surgery and endodontics are the more frequent users of corticosteroids. Most of the corticosteroids prescribed in dentistry are for topical applications or short-term usage, rarely for its systemic effects or for long-term consumption, as in the treatment of some medical conditions. Five years ago, a chapter entitled "The role of Corticosteroids in today's Oral and 
Maxillofacial Surgery" [1] has been published in the book "Glucocorticoids-New Recognition of Our Familiar Friend". The objective of this chapter is therefore to complement the previous publication as well as providing an update on the use of corticosteroids in dentistry, instead of merely oral and maxillofacial surgery.

Although corticosteroids were already used in the field of medicine since 1944, it was not until 1951 that they were introduced to dentistry. Then, Strean published a paper which represented the first scientific approach to the general use of corticosteroids in dentistry [2]. Strean and Horton [3] and Spies et al. [4] were the first to use (hydro)cortisone for the treatment of oral diseases related to local causes and oral manifestations of inflammatory systemic disease. Back then, corticosteroids were prescribed as topical medicament as well as systemic medication, depending on the oral manifestations of systemic diseases. Topical corticosteroids have proven to be effective in treating various oral mucosal lesions including oral ulcerations and oral presentations of auto-immune diseases. In oral medicine, injection of corticosteroids is part of the treatment of temporomandibular joint degeneration.

Corticosteroids are used in oral and maxillofacial surgical procedures to reduce associated post-operative inflammation. The suggestion of their use for managing post-operative sequelae of dentoalveolar surgery began as an editorial by Kenny in 1954 [5]. Following this, Ross and White performed a clinical trial comparing oral hydrocortisone against placebo in a doubleblind study involving third molar surgeries that confirmed the former's efficacy [6]. The most researched outcome on the use of corticosteroids in oral surgery revolves around their effect in reducing post-operative pain, swelling and trismus. Over the last 6 decades, the use of corticosteroids for third molar surgery had been studied extensively in different formulations, dosings, routes and sites of administration [7]. These corticosteroids include dexamethasone (per-oral/p.o.), dexamethasone acetate (intramuscular), dexamethasone sodium phosphate (intravenous and intramuscular), methylprednisolone (p.o.), methylprednisolone acetate and methylprednisolone sodium succinate (both intravenous and intramuscular) [8]. In recent years, a twin-mix combination of $2 \%$ lignocaine with 1:200,000 adrenaline and $4 \mathrm{mg}$ dexamethasone was even given as an inferior alveolar nerve block [9]. A recent review concluded that there are benefits that can be derived from the short-term use of corticosteroids in reducing these inflammatory sequelae, with no side effects observed when given using the methods listed above [7]. However, the use of corticosteroids for periodontal and implant surgeries has not been investigated. The other use of corticosteroids in oral surgery is as medication for various cranial nerve disorders and application/injections for the treatment of facial scars [10]. It is a standard medication for Bell's palsy [11], with prednisolone coupled with acyclovir being the most popular choice. The recommended dose is prednisolone $60-80 \mathrm{mg}$ daily during first 5 days with dose tapering over next 5 days [12]. It is a drug within a cocktail with NSAIDs given to patients suffering from traumatic trigeminal nerve injuries [13]. One study even reported their beneficial effect on lingual and inferior alveolar nerve hypersensitivity following third molar surgery [14]. More controversial use of corticosteroids is related to their administration to patients with maxillofacial space infection. Low et al. recently reported that corticosteroids are useful as adjunct treatment for such cases [15]. Their patients experienced significant clinical improvement with reduction of pain, swelling and trismus, and shortening hospital stay to an average of 3.5 days, in addition to omission of surgical intervention in $50 \%$ of cases. 
Lastly, corticosteroids are used as exposed pulp lining and intracanal medicament in endodontic therapy. This chapter reviews the use of corticosteroids in the three specialties of dentistry as mentioned. It shall answer the routinely asked impression: are dental surgeons and dental specialists still at a cross road in deciding whether corticosteroids should be routinely used in clinical dentistry?

\section{Corticosteroids in oral and maxillofacial surgery}

Corticosteroids are used mainly by oral and maxillofacial surgeons to reduce the post-operative sequelae (pain, swelling and trismus) of dentoalveolar surgery, orthognathic surgery, facial fractures and reconstructive surgery $[16,17]$. Post-operative nausea and vomiting have been reported to be less in patients who were given corticosteroids when these surgeries were done under general anaesthesia [18]. In addition, corticosteroids have been proven to improve interpalpebral width as well as reducing post-operative pain after surgical repair of orbital blowout fractures $[19,20]$. Local steroid injection of the tongue base had proven to reduce the incidence and severity of post-palatoplasty upper airway obstruction in children undergoing cleft palate surgery [21]. A questionnaire survey in North America reported that close to half of oral and maxillofacial surgeons stated that they use short-term, high-dose perioperative corticosteroids to control post-operative oedema [22]. Only 20\% of oral and maxillofacial surgeons claimed that they never use it for dentoalveolar surgery [23]. In comparison, corticosteroids are less preferred for dentoalveolar surgeries by surgeons in at least one European country [16]. Their popularity for dentoalveolar surgeries elsewhere has not been established.

The group of corticosteroids of interest is the glucocorticoids (dexamethasone and betamethasone, and prednisolone and methylprednisolone), because of their anti-inflammatory activities with little or no effect on fluid and electrolyte balance [7]. Their effect has been well studied using the third molar surgery model over the past 6 decades (Table 1). In a study that reviewed the reported outcome of corticosteroids over the last 10 years (2006-2015), Ngeow and Lim [7] reviewed 34 studies that administered corticosteroids via different routes which included intravenous, intramuscular (masseter, deltoid or gluteus), submucosal, endoalveolar and oral administrations. They found that benefits could be derived from the short-term use of corticosteroids with regards to pain, swelling and trismus control following third molar surgery, with no side effects observed. However, there were two limitations to their study, namely restriction to studies performed only throughout the last decade, and exclusion of studies that compared corticosteroids with other drugs, intervention or treatment, except when the corticosteroid was administered with an adjuvant therapy related to third molar surgery, namely an antibiotic.

Some 10 years ago, a systematic review and meta-analysis by Markiewicz et al. [24] reported that perioperative administration of corticosteroids produced a mild to moderate reduction in swelling and improvement of trismus after third molar surgery. More recently, another three meta-analyses specifically reported on the effect of dexamethasone in third molar surgery. Two reviewed the effect of submucosal injection of dexamethasone [25, 26], while the third reviewed the preemptive effect of dexamethasone [27]. The findings of two meta-analyses on submucosal injection are different. Chen et al. reported that submucosal injection of dexamethasone 


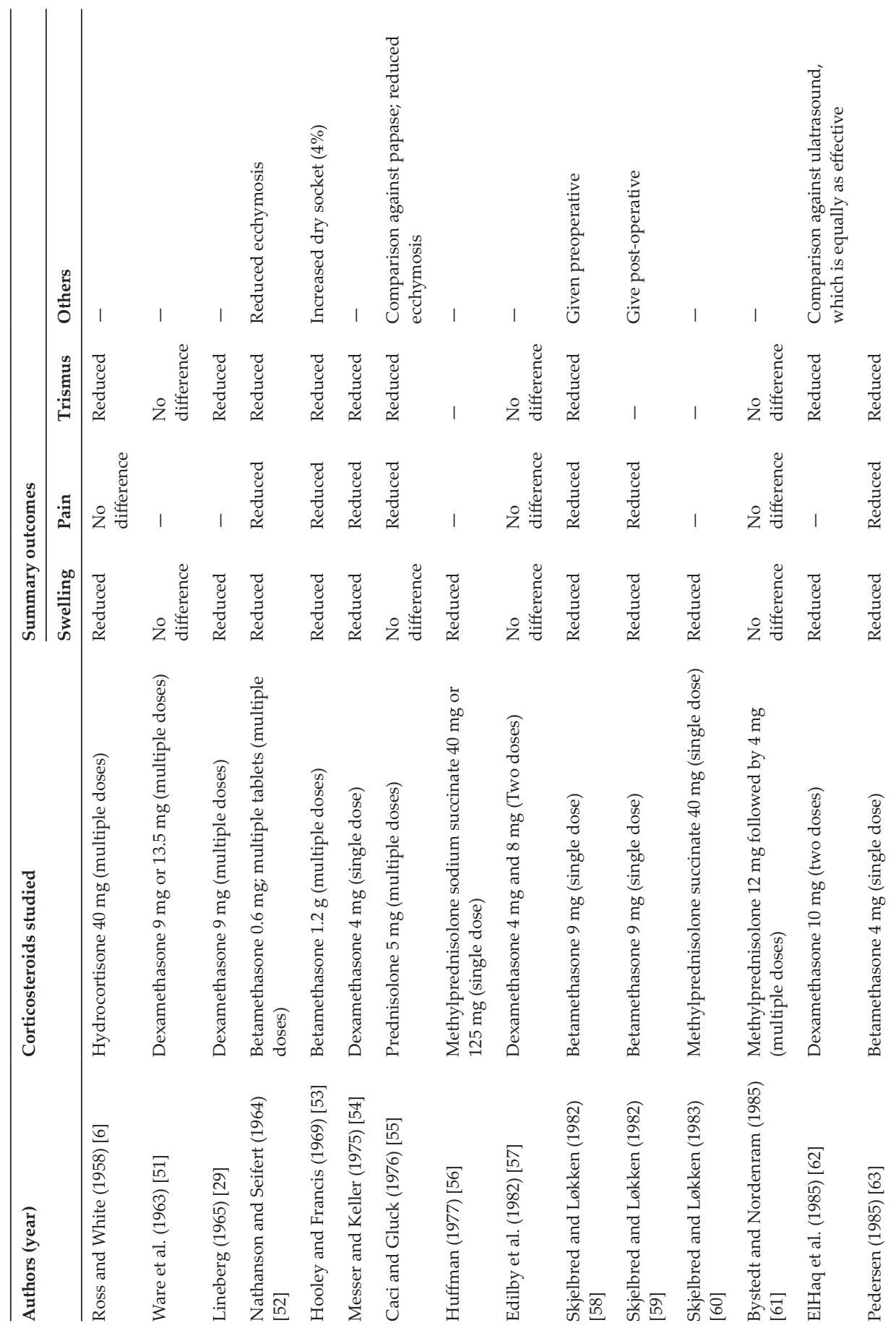




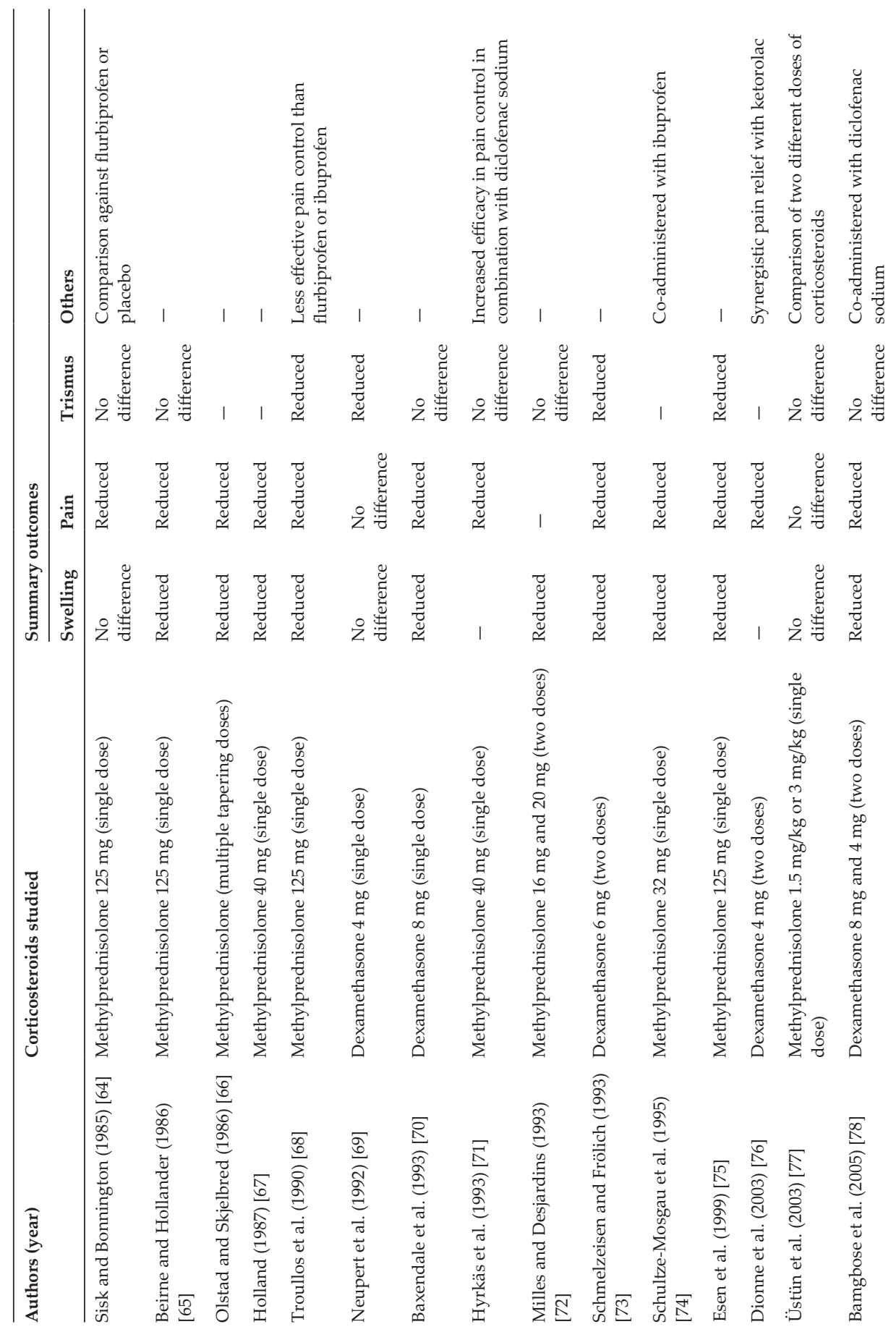




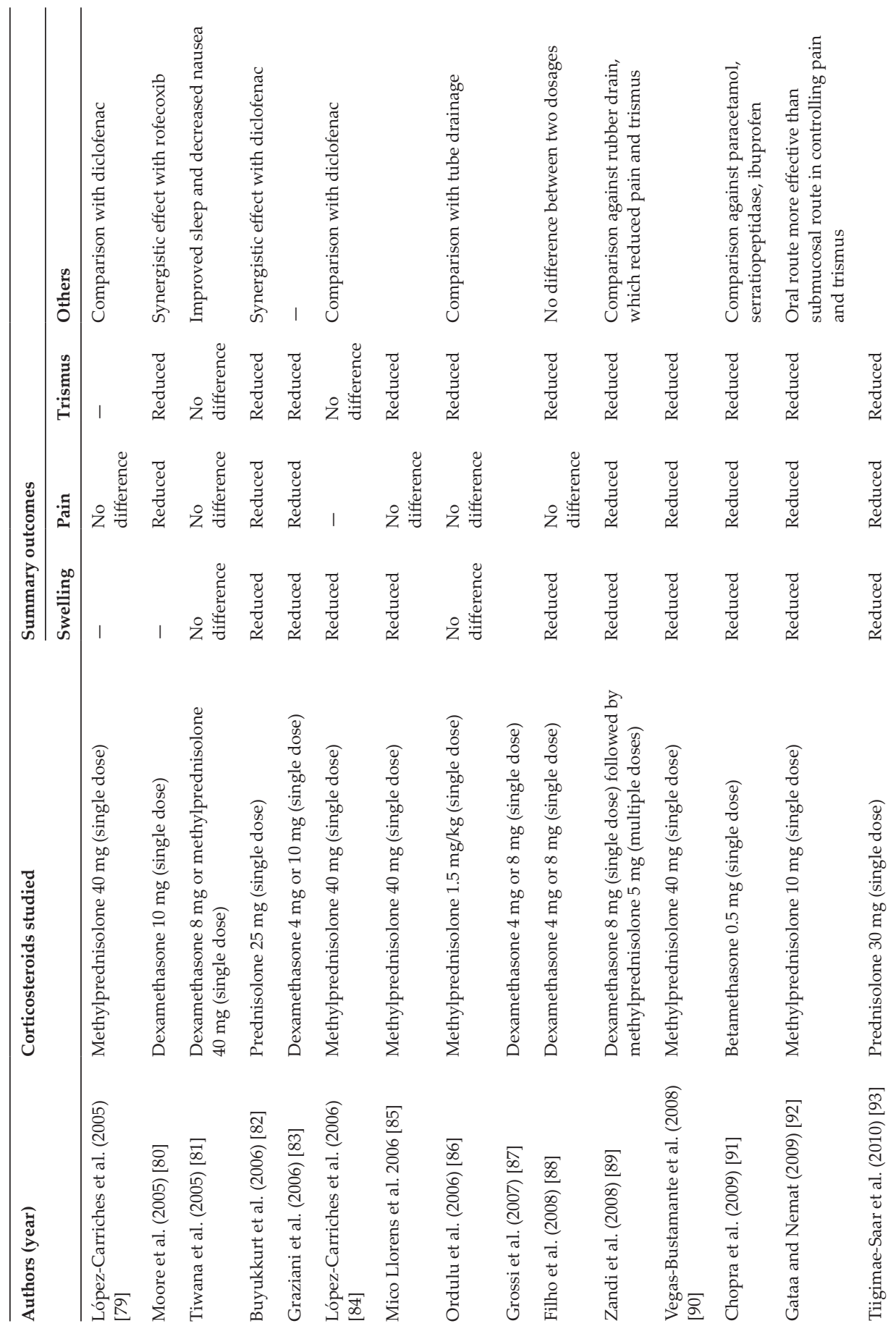




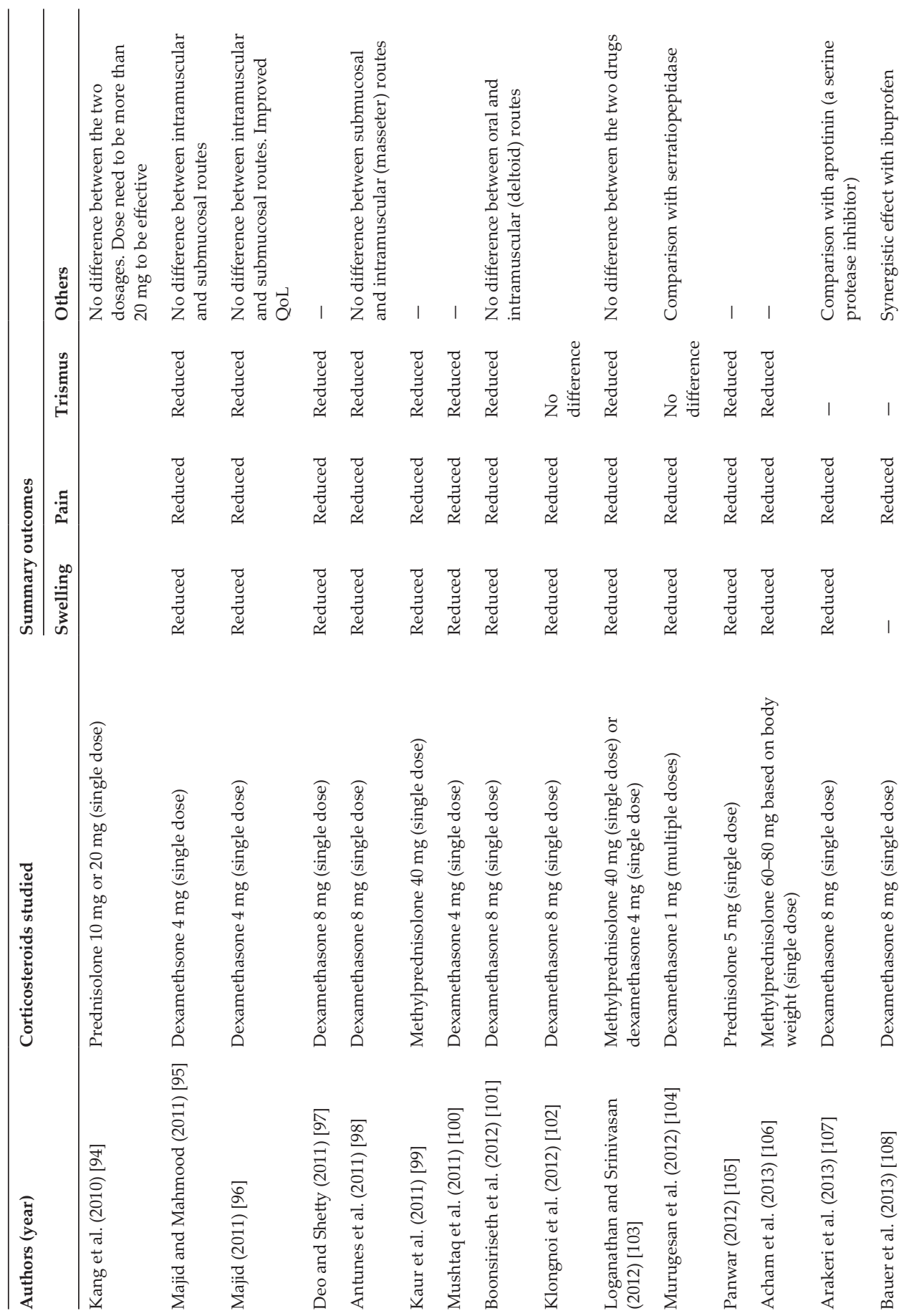




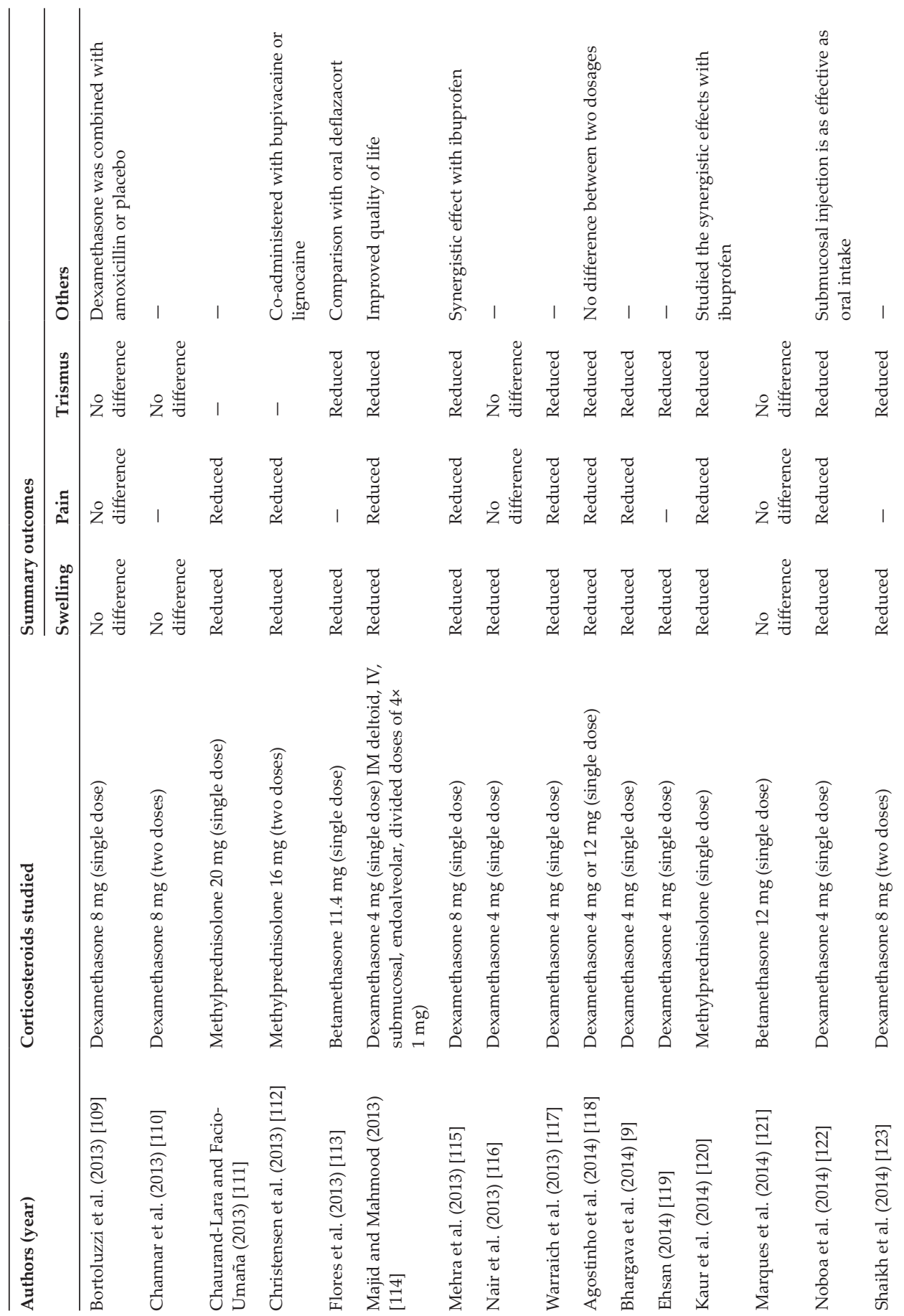




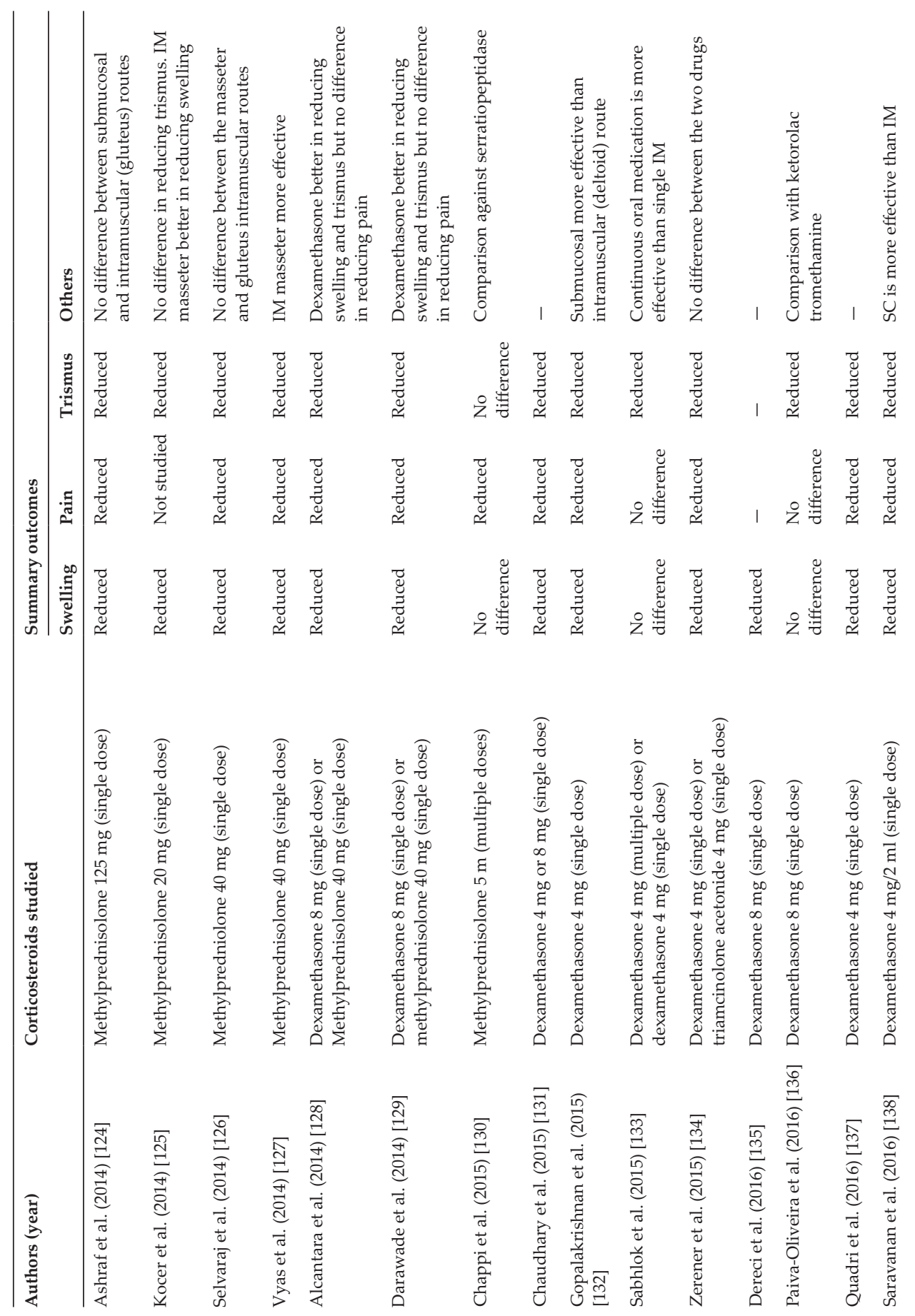




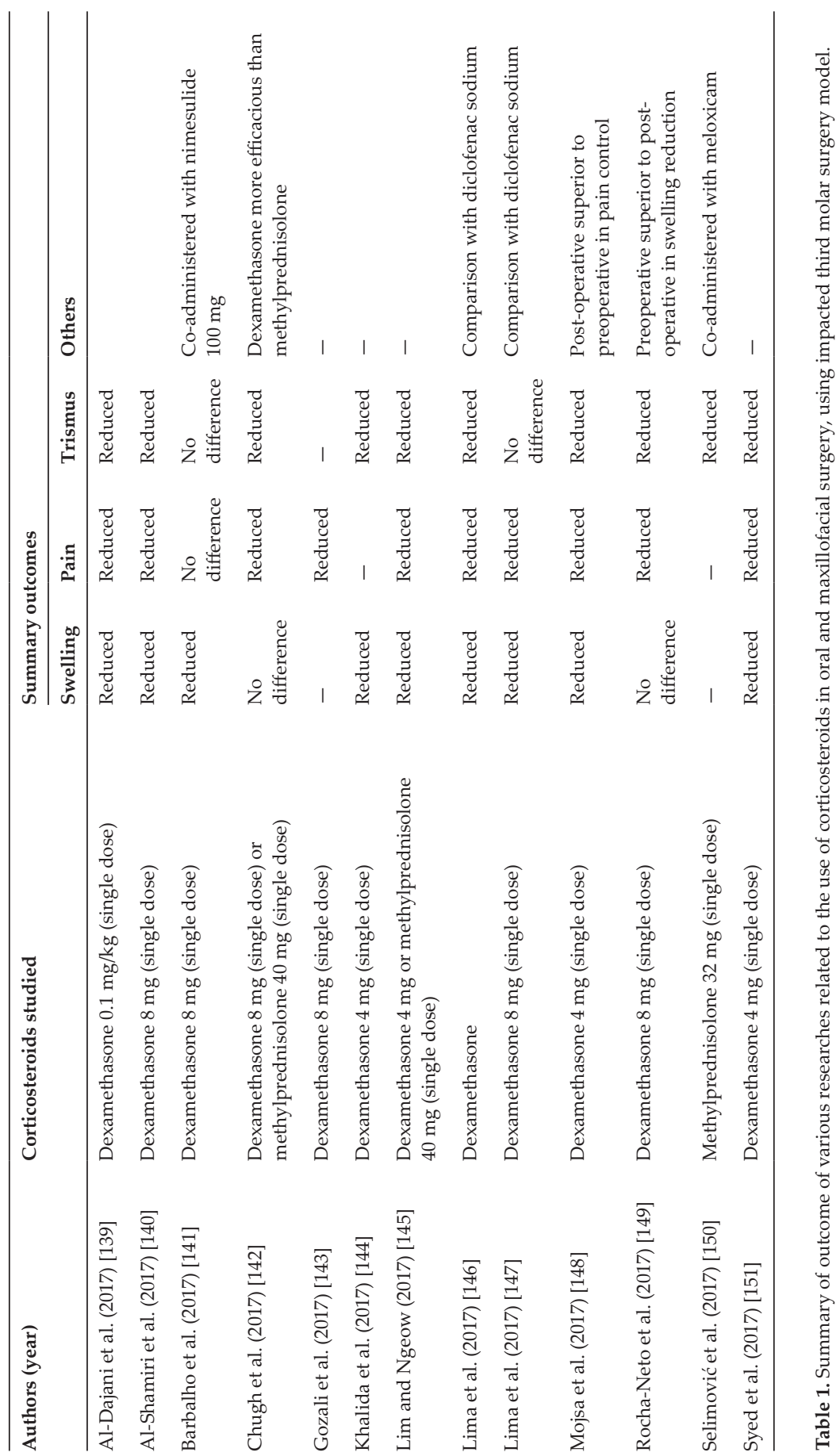


reduced not only early and late oedema but also early trismus [25], while Moraschini et al. reported that submucosal dexamethasone was effective in reducing pain and swelling, but not trismus [26]. The last meta-analysis looking solely on preemptive dexamethasone against other oral anti-inflammatories found that it is more effective than methylprednisolone for reducing swelling and trismus. However, the authors found insufficient evidence to conclude that dexamethasone is better than other nonsteroidal anti-inflammatories or methylprednisolone as a preemptive analgesic [27]. In term of mode of administration, it has been suggested that systemic administration of corticosteroids is more effective [8].

Table 1 summarises all relevant studies on the use of corticosteroids using the third molar surgical model throughout the last 61 years. It shows a change in the trend of corticosteroid prescription, with low-dose single dose being favoured in the last two decades instead of the multiple or high-doses popular in the 1970s till 1990s. However, not many studies have look into the effect of corticosteroids in other oral surgical procedures. One reason for this limitation is the lack of opportunity to perform standardisation that is needed with other oral surgery/ dentoalveolar surgical procedures. Mead et al. and Linenburg were among the few researchers who were able to conduct tests on patients undergoing different types of oral surgical procedure, including third molar surgery [28, 29]. Mead et al. administered oral triamcinolone postoperatively to 96 patients who had undergone varied oral surgical procedures and reported that it was superior to placebo in reducing oedema, pain and trismus [28].

In contrast, Linenburg studied the effect of dexamethasone on patients undergoing treatment of cellulitis and trismus due to an infectious process [29]. He reported a higher percentage of patients treated with corticosteroids being cured of cellulitis and trismus after 4 days than conventional treatment of hospitalisation, antibiotics, drainage and heat application. Linenburg also conducted a trial on 12 patients undergoing a full-mouth or a maxillary alveoloplasty and found that oedema and trismus last longer in patients without dexamethasone. A double-blinded comparison was performed on 50 patients undergoing both removal of bilaterally impacted third molars and full-mouth or maxillary alveoloplasty, and again he found that oedema and trismus last longer in patients without dexamethasone [29].

Not many randomised trials have been undertaken to study the effects of corticosteroids in oral and maxillofacial surgery. With regards to pain and swelling, its effect in traumatology has been studied once only in two separate RCTs; one on patients with blow out fracture [20] and the other on those with mandibular fracture [30]. In the observer-blinded study on the effect of dexamethasone $30 \mathrm{mg}$ in blowout fracture surgery, Kormi et al. concluded that dexamethasone decreased post-operative pain and recommended it as a preemptive analgesic. In comparison, Dongol et al. reported that submucosal administration of dexamethasone after open reduction and internal fixation for mandibular fractures was effective in reducing post-operative swelling and pain. However, they did not observe any significant difference in mouth opening or difficulty in mandibular function [30].

Systemic corticosteroids are used to prevent post-surgical facial oedema, enhance patient comfort and prevent potential upper airway compromise in orthognathic surgery. Several trials even hinted a neuroregenerative effect on inferior alveolar nerve affected by orthognathic surgery [31]. Seo et al. reported that corticosteroids have the potential to accelerate the recovery 
of sensory impairment and it is desirable to start treatment later than 1 week post-operatively. For the record, the first recommendation for using corticosteroids in orthognathic surgery was made by Guernsey and DeChamplain [32] who reviewed complications affecting 22 patients who underwent sagittal ramisection. They suggested that post-operative swelling could be controlled by a regimen of dexamethasone used perioperatively. They described the diminution of post-operative oedema empirically but did not explain how they arrived at their recommended regime of corticosteroids. A study undertaken by Munro et al. [33] 2 years later however, failed to support this recommendation. There are, however, several trials that later confirmed the reduction of swelling in orthognathic patients [17, 34]. Most of them have been meta-analysed and/or underwent systematic review by several authors throughout the last 7 years [35]. Among others, Schaberg et al. reported that perioperative methylprednisolone $(1 \mathrm{mg} / \mathrm{kg})$ was effective in patients who underwent either a Le Fort I osteotomy or a transoral vertical osteotomy, as compared to control patients who were not given this medication [36]. Similarly, Weber and Griffin reported a reduction of swelling when dexamethasone was given perioperatively in patients undergoing bilateral sagittal split osteotomy (BSSO) [37]. This finding has been confirmed by other authors [34] who recently reported that the most effective dose of dexamethasone for bilateral sagittal split osteotomy was $16 \mathrm{mg}$ given preoperatively.

Widar et al. although reported that betamethasone (single dose or multiple repeated dose up to $16 \mathrm{mg}$ ) reduces swelling, it does not reduce neurosensory disturbances over time in patients undergoing bilateral sagittal split osteotomy [17]. Similar findings have been reported by Mensink et al. and Pourdanesh et al. [38, 39]. Similar impact on the neurosensory disturbances after zygomatic complex fracture has been reported recently by Haapanen et al. [40]. Because of the limited number of studies that listed the benefit of administration of corticosteroids in orthognathic surgery, there is still a need for more robust evidence to support their use [41].

Although many studies and systematic reviews found that corticosteroids are beneficial in controlling various post-operative sequelae, there are some who discouraged their use because of the fear of several potential adverse side effects [42]. A most recent systemic review and metaanalysis on the perioperative use of corticosteroids in orthognathic surgery although confirmed that they reduced facial oedema, found that adverse effects were inconsistently screened and reported [37]. The least severe adverse effect is the development of steroid induced acne in some female orthognathic surgery patients [43]. Other more severe complications include adrenal suppression [44], acute psychiatric reactions such as psychosis or inappropriate euphoria [42], a higher infection rate and decreased healing potential.

There are several recent studies that reported conflicting adverse effects with regards to disturbance in surgical wound healing, especially in major oral and maxillofacial surgeries. Thorén et al. in a retrospective study reported that the rate of disturbance in surgical wound healing for patients who had received perioperative steroids was more than twice $(6.0 \%)$ the corresponding rate for patients who did not receive steroids (2.8\%), although this difference was not statistically significant. They reported that intraoral surgical approach was a significant predictor to this adverse effect [45]. Snäll et al. in contrast, did not observe similar problem in operative treatment of mandibular fractures, although they found that older age was a significant predictor of impaired healing [46]. However, in another study on open reduction and fixation 
of zygomatic complex fractures, Snäll et al. reported increased disturbance in surgical wound healing and did not recommend the administration of corticosteroids for such surgery [47].

Other serious complications associated with the administration of corticosteroids are acute gastrointestinal reactions (abdominal pain, haematemesis, and/or maelena), hyperglycemia, superinfection and septicaemia [48] and avascular necrosis of the femoral head [49]. It has been reported that common regimes used in orthognathic surgery involve a total dose of $1830 \mathrm{mg}$ of methylprednisolone over a 30-hour period, a dosage similar to some short-term, high-dose regimens described in orthopaedic case reports of avascular necrosis of the femoral head [49]. Hence, there is a potential risk for this group for patients to develop avascular necrosis. Fortunately, Precious et al., found no evidence that this has occurred in the only study that reviewed the need of total hip replacement in 1276 orthognathic patients. They concluded that the use of systemic corticosteroids for short duration in orthognathic surgery is unlikely related to AVN of the femoral head and the attendant need for total hip replacement [50].

\section{Corticosteroids in oral medicine}

\subsection{Recurrent aphthous ulcer}

Recurrent apthous ulcers top the list of the commonest oral mucosal lesions encountered by any dental practitioners. Generally, this condition is self-limiting and resolves within 2-3 weeks with the exception of major recurrent aphthous ulcer [162]. Despite it being self-limiting, the pain and the frequency of recurrence can be very devastating to the patients. Corticosteroid is one of the available treatment options for recurrent aphthous ulcers.

The use of topical corticosteroids can be advocated when topical anesthetic, antiseptics and anti-inflammatory agents are no longer effective in relieving the discomfort caused by these ulcers. It was suggested to begin with less potent drug such as triamcinolone and moving gradually to more potent corticosteroids like clobetasol [163]. These corticosteroids come in the form of mouthwashes, ointments, creams and adhesive pastes.

Triamcinolone acetonide $0.1 \%$ is the commonly used concentration although it can actually be used at concentration ranging from 0.05 to $0.5 \%$, and is usually applied 3-4 times a day [164]. For maximum effect of the drug, it should be in contact with the ulcer for as long as possible. Therefore, it is advisable to refrain from any oral intake within 20 minutes after application or touching the affected area [164]. Fluocinolone acetonide and clobetasol require lower concentrations of $0.025-0.05 \%$ since they are potent corticosteroid. These drugs are usually applied 4-5 times a day [164]. Al-Na'amah et al. in 2009 studied the use of dexamethasone $0.1 \%$ by comparing it to triamcinolone acetonide $0.1 \%$ and found that both drugs are effective in the treatment of recurrent aphthous ulcers [159].

On the other hand, systemic corticosteroids are rarely required in the treatment of recurrent aphthous ulcers except for cases that are not responsive to topical medications [165]. Oral prednisone with starting dose of $25 \mathrm{mg} /$ day is recommended [165]. This is then followed by tapering 
of the dosage during a period of 2 months. The tapering regime as reported by Femiano et al. in 2003 and 2010 (Table 2) had been shown to be effective in the treatment and prevention of recurrence of aphthous ulcer [161].

\subsection{Oral lichen planus}

Table 3 shows that topical corticosteroids are reasonably effective in the treatment of oral lichen planus. The use of more potent corticosteroids was associated with more improvement following therapy. However, incidence of oral candidiasis also increased in proportion

\begin{tabular}{|c|c|c|c|c|c|}
\hline \multirow[t]{2}{*}{ Authors (year) } & \multirow[t]{2}{*}{ Corticosteroids } & \multicolumn{4}{|l|}{ Outcomes } \\
\hline & & Pain reduction & $\begin{array}{l}\text { Ulcer size } \\
\text { reduction }\end{array}$ & $\begin{array}{l}\text { Duration of } \\
\text { ulcer }\end{array}$ & Recurrence \\
\hline \multicolumn{6}{|l|}{ Topical } \\
\hline $\begin{array}{l}\text { Yeoman (1978) } \\
{[152]}\end{array}$ & $\begin{array}{l}\text { Betamethasone valerate } 1 \text { puff } \\
\text { QID (max } 16 \text { puff/ } 24 \text { hours) }\end{array}$ & Reduced & - & Reduced & - \\
\hline $\begin{array}{l}\text { Pimlott (1983) } \\
\text { [153] }\end{array}$ & $\begin{array}{l}0.05 \% \text { fluocinonide ointment } \\
+ \text { orabase }\end{array}$ & Reduced & - & Reduced & Less \\
\hline $\begin{array}{l}\text { Lo Muzio et al. } \\
\text { (2001) [154] }\end{array}$ & $0.05 \%$ clobetasol ointment & Reduced & - & - & - \\
\hline $\begin{array}{l}\text { Rhodus and } \\
\text { Bereuter (1998) } \\
\text { [155] }\end{array}$ & Kenalog-in-Orabase, TDS & Reduced & - & Reduced & - \\
\hline $\begin{array}{l}\text { Teixeira et al. } \\
\text { (1999) [156] }\end{array}$ & $\begin{array}{l}0.1 \% \text { mometasone furoate } \\
\text { lotion QID }\end{array}$ & Reduced & - & Reduced & - \\
\hline $\begin{array}{l}\text { Rodriguez (2007) } \\
\text { [157] }\end{array}$ & $\begin{array}{l}0.05 \% \text { clobetasol propionate } \\
\text { oral paste QID } \times 5 \text { days }\end{array}$ & Reduced & Faster & - & - \\
\hline $\begin{array}{l}\text { Al-Na'amah et al. } \\
\text { (2009) [158] }\end{array}$ & $\begin{array}{l}\text { Dexamucobase; } 0.1 \% \\
\text { dexamethasone QID }\end{array}$ & Reduced & Faster & Reduced & - \\
\hline $\begin{array}{l}\text { Al-Na'amah et al. } \\
\text { (2009) [158] }\end{array}$ & $\begin{array}{l}\text { Kenalog; } 0.1 \% \text { triamcinolone } \\
\text { acetonide QID }\end{array}$ & Reduced & Fast & Reduced & - \\
\hline $\begin{array}{l}\text { Fani et al. (2012) } \\
\text { [159] }\end{array}$ & $\begin{array}{l}0.1 \% \text { triamcinolone acetonide } \\
\text { ointment TDS }\end{array}$ & \multicolumn{4}{|c|}{ Significantly better therapeutic effect in triamcinolone group } \\
\hline \multicolumn{6}{|l|}{ Systemic } \\
\hline $\begin{array}{l}\text { Femiano et al. } \\
(2003) \text { [160] }\end{array}$ & $\begin{array}{l}\text { Prednisone } \\
25 \mathrm{mg} \text { OD } \times 1 \text { week, } 20 \mathrm{mg} \\
\text { OD } \times 2 \text { weeks, } 15 \mathrm{mg} \text { OD } \times \\
2 \text { weeks, } 10 \mathrm{mg} \text { OD } \times 2 \text { weeks, } \\
5 \mathrm{mg} \text { OD } \times 1 \text { week }\end{array}$ & Reduced & - & Reduced & Less \\
\hline $\begin{array}{l}\text { Femiano et al. } \\
(2010) \text { [161] }\end{array}$ & $\begin{array}{l}\text { Prednisone } \\
25 \mathrm{mg} \text { OD } \times 15 \text { days, } 12.5 \mathrm{mg} \\
\mathrm{OD} \times 15 \text { days, } 6.25 \mathrm{mg} \text { OD } \\
\times 15 \text { days, } 6.25 \mathrm{mg} \text { EOD } \times \\
15 \text { days }\end{array}$ & Reduced. & - & Reduced & Less \\
\hline
\end{tabular}

Table 2. Topical and systemic corticosteroids used in the treatment of recurrent aphthous ulcer. 


\begin{tabular}{|c|c|c|c|c|}
\hline \multirow[t]{2}{*}{ Corticosteroid } & \multirow[t]{2}{*}{ Author (year) } & \multicolumn{3}{|l|}{ Results (\%) } \\
\hline & & $\begin{array}{l}\text { Complete } \\
\text { response }\end{array}$ & Partial response & No response \\
\hline Hydrocortisone hemisuccinate & Holbrook et al. (1988) [165] & 48 & 37 & 15 \\
\hline $\begin{array}{l}\text { Betamethasone sodium } \\
\text { phosphate }\end{array}$ & Hegarty et al. (2002) [166] & 0 & 73 & 27 \\
\hline Betamethasone valerate $0.1 \mathrm{mg}$ & Cawson (1968) [167] & 43 & 23 & 34 \\
\hline Triamcinolone acetonide $0.1 \%$ & $\begin{array}{l}\text { Thongprasom et al. (1992) } \\
\text { [168] }\end{array}$ & 42 & Not mentioned & Not mentioned \\
\hline Fluocinolone acetonide $0.1 \%$ & $\begin{array}{l}\text { Thongprasom et al. (1992) } \\
\text { [168] }\end{array}$ & 68 & Not mentioned & Not mentioned \\
\hline \multirow[t]{3}{*}{ Fluocinonide $0.05 \%$} & $\begin{array}{l}\text { Lozada and Silverman } \\
\text { (1980) [169] }\end{array}$ & 52 & 48 & 0 \\
\hline & Voute et al. (1993) [170] & 20 & 60 & 20 \\
\hline & Carbone et al. (1999) [171] & 25 & 65 & 10 \\
\hline Fluticasone propionate $0.05 \%$ & Hegarty et al. (2002) [166] & 0 & 80 & 20 \\
\hline \multirow[t]{4}{*}{ Clobetasol propionate $0.05 \%$} & $\begin{array}{l}\text { Lozada-Nur et al. (1991) } \\
\text { [172] }\end{array}$ & 56 & 22 & 22 \\
\hline & Sardella et al. (1988) [173] & 57 & 21.5 & 21.5 \\
\hline & Carbone et al. (1999) [170] & 75 & 25 & 0 \\
\hline & $\begin{array}{l}\text { Gonzales-Moles et al. (2002) } \\
\text { [174] }\end{array}$ & 93 & 0 & 7 \\
\hline
\end{tabular}

Table 3. Topical corticosteroids used in the treatment of oral lichen planus.

to the potency of corticosteroids used [169, 171]. Carbone et al. in 2003 reported that the use of topical corticosteroid can be as effective or even more effective than systemic corticosteroids in the treatment of oral lichen planus [175]. On the other hand, the use of systemic corticosteroids should be restricted to acute exacerbations or multiple lesions. Topical regime can be prescribed in combination of systemic regime to reduce side effects of systemic corticosteroids [176]. The commonly used systemic corticosteroid is prednisone which is usually prescribed within the range of $40-80 \mathrm{mg} /$ day to achieve clinical response. To avoid adverse effects of this drug, it is best to prescribe the lowest dose for the shortest duration possible. To achieve this, prednisone can either be given for a brief period of 5-7 days and stop abruptly or the dose can be tapered down by $5-10 \mathrm{mg} /$ day gradually over a period of 2-4 weeks [177].

Intralesional injection is another alternative for administrating corticosteroids in the treatment of oral lichen planus. Hydrocortisone, dexamethasone, betamethasone, triamcinolone acetonide and methylprednisolone have been used for intralesion injection. This method is however, painful and causes localised mucosal atrophy. Intralesional injection is also not feasible in cases of multiple widespread lesions [176, 178]. 


\subsection{Pemphigus vulgaris and mucous membrane pemphigoid}

Corticosteroids have become the mainstay of treatment for pemphigus ever since the first case series reported by Ryan in 1971 [179]. Despite being the gold standard in the treatment of pemphigus, the use of corticosteroids is still mulled by many physicians due to the adverse effects of long-term treatment and difficulty in ascertaining the best regimen [180]. Due to the high mortality rate of this condition, studies conducted were just comparing various groups of drugs used, different dosages and modes of administration rather than purely investigating the efficacy of a particular drug. Most of the articles published were mainly case reports and case series [181].

More than three-quarter of the patients with pemphigus vulgaris presented with oral lesions. And these lesions are the presenting signs of half of the patients diagnosed with pemphigus vulgaris [182]. As in the treatment of oral lesions in pemphigus vulgaris, oral lesions secondary to mucous membrane pemphigoid are also treated with moderate to high potency topical corticosteroids (fluocinonide $0.05 \%$, clobetasol $0.05 \%$ ), applied $2-3$ times per day. The frequency of application can be tapered gradually with improvement of symptoms [182]. Bear in mind that as a result of prolonged topical corticosteroids use, infection such as candidiasis and reactivation herpes simplex virus can occur. Combination of other drugs such as dapsone, tetracycline and nicotinamide is recommended.

As for systemic corticosteroids, an initial dose of $0.5-1 \mathrm{mg} / \mathrm{kg} /$ day of prednisone plus adjuvant immunosuppressants is recommended. This dose is continued until all existing lesions have healed and no development of new lesions is noticed clinically. Once this is achieved, tapering of the dose can be performed [182]. The ultimate aim in the treatment strategy is to minimise the dose of systemic corticosteroids while controlling the disease with immunosuppressants.

In patient with severe pemphigus vulgaris, corticosteroid pulse therapy can be administered to induce remission. In this therapy, a very high-dose of corticosteroid (500-1000 mg methylprednisolone or 100-200 mg dexamethasone given in divided dose on 3 consecutive days) is given in a short period of time in combination immunosuppressants and maintenance dose of corticosteroids [183].

\subsection{Bell's palsy}

With an unclear knowledge of the aetiology of Bell's palsy, it poses a great challenge in coming up with an optimal treatment of the condition. To achieve a good outcome, corticosteroid needs to be given within 72 hours of onset of facial palsy. Berg et al. in 2012 found that prednisolone given within 72 hours of onset of palsy significantly improve outcome in mild to moderate palsy but not in severe palsy. The regime used was prednisolone $60 \mathrm{mg} /$ day for 5 days, followed by $10 \mathrm{mg} /$ day for another 5 days [184]. Using the same regimen, another study found that prednisolone significantly achieve complete recovery in mild to severe palsy and less synkinesis observed in mild and moderate palsy. However, no significant reduction of synkinesis in severe cases was reported [185]. Murthy and Saxena in 2011 suggested two corticosteroid regimens for the treatment of Bell's palsy which were either prednisolone $60 \mathrm{mg} /$ day for 5 days followed by $10 \mathrm{mg} /$ day for another 5 days or prednisolone $25 \mathrm{mg}$ twice a day for 10 days [186]. The American Academy of Otolaryngology-Head and Neck Surgery recommended a 10-day course of oral 
steroids with at least 5 days at a high-dose (either prednisolone $50 \mathrm{mg}$ for 10 days or prednisone $60 \mathrm{mg}$ for 5 days with a 5-day taper) initiated within 72 hours of symptom onset [187].

Conflicting results were reported in different studies on the benefit of combining anti viral therapy with corticosteroid to achieve better outcome. Minnerop et al. reported that combination of famciclovir and prednisone was superior to prednisone alone in cases of severe Bell's palsy [188]. Combining antiviral therapy with prednisone increase the recovery rate slightly but not significantly compared to prednisone monotherapy [189]. On the other hand, valacyclovir was found to have no additional effect to prednisolone in sequelae of Bell's palsy [869] and the addition of acyclovir to prednisolone did not significantly improve recovery from Bell's palsy [190]. Despite conflicting results from various studies, Madhok et al. in their Cochrane review in 2016 concurred with current evidences that corticosteroids showed significant benefit in the treatment of Bell's palsy [191].

\subsection{Temporomandibular joint}

In year 1953, Horten reported the use of intraarticular injection of steroids into the temporomandibular joint (TMJ) space. Being the first to perform this procedure in the TMJ, he was then inspired by Hollander and colleagues' work where they injected hydrocortisone into other arthritic joints [192]. Kopp et al. in 1985 injected betamethasone into the TMJ space in a group of patients with TMJ pain and dysfunction, showed that betamethasone was effective in reducing joint pain up to 4 weeks [193]. About 6 years later, Kopp and colleagues performed intraarticular injection using methylprednisolone which showed similar promising results up to 4 weeks [194]. Bjørnland et al. injected betamethasone into the TMJ space of patients with osteoarthritis and myofascial pain 10 years ago. Although betamethasone managed to reduce joint pain, sodium hyaluronate which was given in the other study group was found to be more effective [195]. Another promising use of corticosteroids is for the management of disc displacement without reduction. Samiee et al. found that combined intraarticular injection of local anaesthetic and corticosteroids improved mouth opening [196].

Using computed tomography (CT) scan, Møystad et al. evaluated the bony changes in osteoarthritic TMJ following intraarticular injection of sodium hyaluronate and corticosteroid (betamethasone). The number of cases that showed disease progression, regression and no changes were almost equal [197]. This finding raised the question on the effectiveness of corticosteroids as intraarticular injection. Another study by Bouloux et al. recently again showed no added effect of using corticosteroids or another agent, hyaluronic acid in arthrocentesis [198]. In cases of juvenile idiopathic arthritis, a study by Resnick et al. showed that although intraarticular corticosteroid (triamcinolone hexacetonide) injection did reduce TMJ sinovitis pain, its efficacy for long-term inflammation and joint destruction control needs further studies.

\section{Corticosteroids in endodontology}

The first intracanal medication using corticosteroids was reported by Wolfsohn in 1954 . In that study, he showed that hydrocortisone was effective in reducing severe secondary 
inflammatory reactions in the apical periodontal tissue following endodontic treatment [208]. Other authors who also used corticosteroids as intracanal medication, as listed in Table 4, reported beneficial outcome in the post-operative or post-instrumentation pain. Besides reducing pain, Thong et al. reported that the use of corticosteroid-antibiotic and calcium hydroxide significantly inhibited periodontal ligament inflammation and inflammatory root resorption [209]. A well-known intracanal medication, Ledermix ${ }^{\circledR}$, is corticosteroidantibiotic compound which consists of $1 \%$ triamcinolone acetonide and $3.2 \%$ demeclocycline hydrochloride in a polyethylene glycol base. The function of antibiotic in that paste is to compensate for the possible corticosteroid-induced immunosuppessing effect [210]. Despite being an effective intracanal medication, Ledermix ${ }^{\circledast}$ was found to cause discolouration of the teeth especially when it is placed above the cementoenamel junction. Therefore, to avoid this Ledermix ${ }^{\circledR}$ should be placed below the gingival margin [211].

Similar to the use of corticosteroids in third molar surgery, local injection of corticosteroids have been found to reduce post treatment pain. Kaufman et al. evaluated the effect of intraligamental injection of corticosteroids on post treatment pain. They found that intraligamental injection of methylprednisolone significantly decreased post treatment pain [202]. Nobuhara et al. in their histological study found that local infiltration of dexamethasone significantly reduced inflammation of the periapical tissue [212].

\begin{tabular}{|c|c|c|}
\hline \multirow[t]{2}{*}{ Author (year) } & \multirow[t]{2}{*}{ Corticosteroids } & \multirow{2}{*}{$\begin{array}{l}\text { Outcome } \\
\begin{array}{l}\text { Post treatment } \\
\text { pain }\end{array}\end{array}$} \\
\hline & & \\
\hline \multicolumn{3}{|l|}{ Intracanal } \\
\hline Rogers et al. (1999) [199] & $\begin{array}{l}\text { Dexamethasone } 0.4 \mathrm{mg} \text { (intracanal) and ketorolac tromethamine } \\
3 \mathrm{mg} \text { (intracanal) }\end{array}$ & Reduced \\
\hline Negm (2001) [200] & Kenacomb (antibiotics and triamcinolone acetonide $0.1 \%$ ) & Reduced \\
\hline Ehrmann et al. (2003) [201] & Ledermix ( $1 \%$ triamcinolone acetonide, 3.2\% demeclocycline) & Reduced \\
\hline \multicolumn{3}{|l|}{ Local (injection) } \\
\hline Kaufman et al. (1994) [202] & 4-8 mg methylprednisolone (intraligamental injection) & Reduced \\
\hline \multicolumn{3}{|l|}{ Systemic } \\
\hline $\begin{array}{l}\text { Stewart and Chilton (1958) } \\
\text { [203] }\end{array}$ & $\begin{array}{l}\text { Metreton ( } 2.5 \mathrm{mg} \text { prednisone, } 2 \mathrm{mg} \text { chlopheniramine) TDS } \times 2 \text { days, } \\
\text { penicillin } 250 \mathrm{mg} \text { TDS } \times 3 \text { days }\end{array}$ & Reduced \\
\hline Stewart (1962) [204] & Dexamethasone $0.75 \mathrm{mg} \mathrm{BD} \times 2$ days & Reduced \\
\hline $\begin{array}{l}\text { Krasner and Jackson (1986) } \\
\text { [205] }\end{array}$ & $\begin{array}{l}\text { Dexamethasone } 0.75 \mathrm{mg} \times 7 \text { tablets, } 3 \text { tablets immediately after } \\
\text { procedure, one tablet every } 3 \text { hours }\end{array}$ & Reduced \\
\hline Glassman et al. (1989) [206] & $\begin{array}{l}\text { Dexamethsone } 4 \mathrm{mg} \times 3 \text { tablets, one tablet taken immediately after } \\
\text { procedure, one tablet every } 4 \text { hours }\end{array}$ & Reduced \\
\hline Liesinger et al. (1993) [207] & Dexamethasone $0.07-0.09 \mathrm{mg} / \mathrm{kg}$ (intramuscular injection) & Reduced \\
\hline
\end{tabular}

Table 4. Studies on usage of corticosteroids via various routes of administration. 
From the studies shown in Table 4, it is obvious that they confirmed the favourable result of systemic administration of corticosteroids in alleviating post treatment pain. In all the studies, corticosteroids were only given for a very short period. Therefore, the possibility of adverse effects arising from short-term corticosteroids is very unlikely [7].

\section{Conclusion}

The uses of corticosteroids are very well established in the field of oral medicine and endodontology. On the other hand, in the field of oral and maxillofacial surgery, despite being consistently effective in controlling post-surgical oedema, corticosteroids provide rather less consistent outcome in pain control as well as trismus reduction. Its impact on wound healing is varied.

\section{Author details}

Wei Cheong Ngeow*, Daniel Lim and Nurhalim Ahmad

*Address all correspondence to: ngeowy@um.edu.my

Faculty of Dentistry, University of Malaya, Kuala Lumpur, Malaysia

\section{References}

[1] Zandi M. The role of corticosteroids in today's oral and maxillofacial surgery. In: Qian X, editor. Glucocorticoids-New Recognition of Our Familiar Friend. InTech; 2012. DOI: 10.5772/48655. Available from: https://www.intechopen.com/books/glucocorticoidsnew-recognition-of-our-familiar-friend/the-role-of-corticosteroids-in-today-s-oral-andmaxillofacial-surgery

[2] Strean LP. The possible role of cortisone in dentistry. New York Journal of Dentistry. 1951; 22:102-104

[3] Strean LP, Horton C. Hydrocortisone in dental practice. Dental Digest. 1954;59:8-16

[4] Spies TD, Dreizen S, Stone RE, Garcia-Lopez G, Lopez-Toca R, Reboredo A. A clinical appraisal of ACTH and cortisone as therapeutic agents in dental medicine. Oral Surgery, Oral Medicine, and Oral Pathology. 1952;5:25-40

[5] Kenny FA. Editorial \& clinical observation. Journal of Oral Surgery. 1954;12:314

[6] Ross R, White CP. Evaluation of hydrocortisone in prevention of postoperative complications after oral surgery: A preliminary report. Journal of Oral Surgery. 1958;16:220-226 
[7] Ngeow WC, Lim D. Do corticosteroids still have a role in the management of third molar surgery? Advances in Therapy. 2016;33:1105-1139. DOI: 10.1007/s12325-016-0357-y

[8] Alexander R, Throndson R. A review of perioperative corticosteroid use in dentoalveolar surgery. Oral Surgery, Oral Medicine, Oral Pathology, Oral Radiology, and Endodontics. 2000;90:406-415. DOI: 10.1067/moe.2000.109778

[9] Bhargava D, Sreekumar K, Deshpande A. Effects of intra-space injection of twin mix versus intraoral-submucosal, intramuscular, intravenous and per-oral administration of dexamethasone on post-operative sequelae after mandibular impacted third molar surgery: A preliminary clinical comparative study. Oral and Maxillofacial Surgery. 2014;18:293-296. DOI: $10.1007 / \mathrm{s} 10006-013-0412-7$

[10] Carroll W, Patel K. Steroids and fluorouracil for keloids and hypertrophic scars. JAMA Facial Plastic Surgery. 2015;17:77-79. DOI: 10.1001/jamafacial.2014.1355

[11] Lagalla G, Logullo F, Di Bella P, Provinciali L, Ceravolo MG. Influence of early high-dose steroid treatment on Bell's palsy evolution. Neurological Sciences. 2002;23:107-112. DOI: $10.1007 / \mathrm{s} 100720200035$

[12] Baker PR. Diagnosis and management of Bell's palsy. Oral and Maxillofacial Surgery Clinics of North America. 2000;12:303-308

[13] Greenstein G, Carpentieri JR, Cavallaro J. Nerve damage related to implant dentistry: Incidence, diagnosis, and management. The Compendium of Continuing Education in Dentistry. 2015;36:652-659

[14] Barron RP, Benoliel R, Zeltser R, Eljay E, Nahlieli O, Gracely RH. Effect of dexamethasone and dipyrone on lingual and inferior alveolar nerve hypersensitivity following third molar extractions: Preliminary report. Journal of Orofacial Pain. 2014;18:62-68

[15] Low LF, Audimulam H, Lim HW, Selvaraju K, Balasundram S. Steroids in maxillofacial space infection: A retrospective cohort study. Open Journal of Stomatology. 2017;7:397407. DOI: $10.4236 /$ ojst.2017.79034

[16] Kormi E, Snäll J, Törnwall J, Thorén H. A survey of the use of perioperative glucocorticoids in oral and maxillofacial surgery. Journal of Oral and Maxillofacial Surgery. 2016;74:15481551. DOI: 10.1016/j.joms.2016.02.027

[17] Widar F, Kashani H, Alsén B, Dahlin C, Rasmusson L. The effects of steroids in preventing facial oedema, pain, and neurosensory disturbances after bilateral sagittal split osteotomy: A randomized controlled trial. International Journal of Oral and Maxillofacial Surgery. 2015;44:252-258. DOI: 10.1016/j.ijom.2014.08.002

[18] Baxendale BR, Vater M, Lavery KM. Dexamethasone reduces pain and swelling following extraction of third molar teeth. Anaesthesia. 1993;48:961-964

[19] Flood TR, McManners J, el-Attar A, Moos KF. Randomized prospective study of the influence of steroids on postoperative eye-opening after exploration of the orbital floor. The British Journal of Oral \& Maxillofacial Surgery. 1999;37:312-315

[20] Kormi E, Snäll J, Koivusalo AM, Suominen AL, Thorén H, Törnwall J. Analgesic effect of perioperative systemic dexamethasone on blowout fracture surgery. Journal of Oral and Maxillofacial Surgery. 2017;75:1232-1237. DOI: 10.1016/j/joms.2016.09.026 
[21] Abdel-Aziz M, Ahmed A, Naguib N, Abdel-Khalik MI. The effect of steroid injection of the tongue base on reducing postoperative airway obstruction in cleft palate repair. International Journal of Oral and Maxillofacial Surgery. 2012;41:612-615. DOI: 10.1016/j. ijom.2012.01.013

[22] Assimes T, Lessard ML. The use of perioperative corticosteroids in craniomaxillofacial surgery. Plastic and Reconstructive Surgery. 1999;103:313-321

[23] Moore PA, Nahouraii HS, Zovko JG, Wisniewski SR. Dental therapeutic practice patterns I the U.S. II. Analgesics, corticosteroids, and antibiotics. General Dentistry. 2006;54:201-207

[24] Markiewicz MR, Brady MF, Ding EL, Dodson TB. Corticostreoids reduce postoperative morbidity after third molar surgery: A systematic review and meta-analysis. Journal of Oral and Maxillofacial Surgery. 2008;66:1881-1894. DOI: 10.1016/j.joms.2008.04.022

[25] Chen Q, Chen J, Hu B, Feng G, Song J. Submucosal injection of dexamethasone reduces postoperative discomfort after third-molar extraction: A systemic review and metaanalysis. Journal of the American Dental Association. 2017;148:81-91. DOI: 10.1016/j. adaj.2016.09.014

[26] Moraschini V, Hidalgo R, Porto Barboza E. Effect of submucosal injection of dexamethasone after third molar surgery: A meta-analysis of randomized controlled trials. International Journal of Oral and Maxillofacial Surgery. 2016;45:232-240. DOI: 10.1016/j. ijom.2015.09.008

[27] Falci SGM, Lima TC, Martins CC, Santos CRRD, Pinheiro MLP. Preemptive effect of dexamethasone in third-molar surgery: A meta-analysis. Anesthesia Progress. 2017;64:136-143. DOI: $10.2344 /$ anpr-64-05-08

[28] Mead SV, Lynch DF, Mead SC, Wolkowicz J. Triamcinolone given orally to control postoperative reactions to oral surgery. Journal of Oral Surgery. 1964;22:484-487

[29] Linenberg W. The clinical evaluation of dexamethasone in oral surgery. Oral Surgery, Oral Medicine, and Oral Pathology. 1965;20:6-28

[30] Dongol A, Jaisani MR, Pradhan L, Dulal S, Sagtani A. A randomized clinical trial of the effects of submucosal dexamethasone after surgery for mandibular fractures. Journal of Oral and Maxillofacial Surgery. 2015;73:1124-1132. DOI: 10.1016/j.joms.2014.12.042

[31] Seo K, Tanaka Y, Terumitsu M, Someya G. Efficacy of steroid treatment for sensory impairment after orthognathic surgery. Journal of Oral and Maxillofacial Surgery. 2004; 62:1193-1197

[32] Guernsey LH, DeChamplain RW. Sequelae of complications of the intraoral sagittal oseotomy in the mandibular rami. Oral Surgery. 1971;32:176-192

[33] Munro IR, Boyd JB, Wainwright DJ. Effect of steroids in maxillofacial surgery. Annals of Plastic Surgery. 1986;17:440-444

[34] Abukawa H, Ogawa T, Kono M, Koizumi T, Kawase-Koga Y, Chikazu D. Intravenous dexamethasone administration before orthognathic surgery reduces the postoperative edema 
fo the masseter muscle: A randomized controlled trial. Journal of Oral and Maxillofacial Surgery. 2017;75:1257-1262. DOI: 10.1016/j.joms.2016.12.048

[35] Jean S, Dionne PL, Bouchard C, Giasson L, Turgeon AF. Perioperative systemic corticosteroids in orthognathic surgery: A systematic review and meta-analysis. Journal of Oral and Maxillofacial Surgery. DOI: 10.1016/j.joms.2017.06.014

[36] Schaberg SJ, Stuller CB, Edwards SM. Effect of methylprednisolone on swelling after orthognathic surgery. Journal of Oral and Maxillofacial Surgery. 1984;42:356-361

[37] Weber CR, Griffin JM. Evaluation of dexamethasone for reducing postoperative edema and inflammatory response after orthognathic surgery. Journal of Oral and Maxillofacial Surgery. 1994;52:35-39

[38] Mensink G, Zweers A, Wolterbeek R, Dicker GG, Groot RH, van Merkesteyn RJ. Neurosensory disturbances one year after bilateral sagittal split osteotomy of the mandibula performed with separators: A multi-centre prospective study. Journal of Cranio-MaxilloFacial Surgery. 2012;40:763-767. DOI: 10.1016/j.jcms.2012.02.003

[39] Pourdanesh F, Khayampour A, Jamalian A. Therapeutic effects of local application of dexamethasone during bilateral sagittal split ramus osteotomy surgery. Journal of Oral and Maxillofacial Surgery. 2014;72:1391-1394. DOI: 10.1016/j.joms.2013.12.025

[40] Haapanen A, Thorén H, Apajalahti S, Suominen AL, Snäll J. Does dexamethasone facilitate neurosensory function regeneration after zygomatic fracture? A randomized controlled trial. Journal of Oral and Maxillofacial Surgery. DOI: 10.1016/j.joms.2017.08.009

[41] Chegini S, Dhariwal DK. Review of evidence for the use of steroids in orthognathic surgery. The British Journal of Oral \& Maxillofacial Surgery. 2012;50:97-101. DOI: 10.1016/j. bjoms.2010.11.019

[42] Galen DM, Beck M, Buchbinder D. Steroid psychosis after orthognathic surgery: A case report. Journal of Oral and Maxillofacial Surgery. 1997;55:294-297

[43] Precious DS, Hoffman CD, Miller R. Steroid acne after orthognathic surgery. Oral Surgery, Oral Medicine, Oral Pathology and Oral Radiology. 1992;74:279-281

[44] Cawson RA, James J. Adrenal crisis in a dental patient having systemic corticosteroid. The British Journal of Oral Surgery. 1973;10:305-309

[45] Thorén H, Snäll J, Kormi E, Numminen L, Fäh R, Iizuka T, Lindqvist C, Törnwall J. Does perioperative glucocorticosteroid treatment correlate with disturbance in surgical wound healing after treatment of facial fractures? A retrospective study. Journal of Oral and Maxillofacial Surgery. 2009;67:1884-1888. DOI: 10.1016/j.joms.2009.04.089

[46] SnällJ, Kormi E, Lindqvist C, Suominen AL, Mesimäki K, Törnwall J, Thorén H. Impairment of wound healing after operative treatment of mandibular fractures, and the influence of dexamethasone. The British Journal of Oral \& Maxillofacial Surgery. 2013;51:808-812. DOI: 10.1016/j.bjoms.2013.08.015 
[47] Snäll J, Kormi E, Koivusalo AM, Lindqvist C, Suominen AL, Törnwall J, Thorén H. Effects of perioperatively administered dexamethasone on surgical wound healing in patients undergoing surgery for zygomatic fracture: A prospective study. Oral Surgery, Oral Medicine, Oral Pathology, Oral Radiology. 2014;117:685-659. DOI: 10.1016/j. oooo.2014.02.033

[48] Boston Collaborative Drug Surveillance Program: Acute adverse reactions to prednisone in relation to dosage. Clinical Pharmacology and Therapeutics. 1972;13:694-698

[49] Anderson JM, Helm R. Multiple joint osteonecrosis following short-term steroid therapy: Case report. The Journal of Bone and Joint Surgery. American Volume. 1982;64:139-141

[50] Precious D, Armstrong J, Morrison A, Field C. The incidence of total hip replacement in orthognathic surgery patients receiving short-term steroid therapy. Journal of Oral and Maxillofacial Surgery. 1992;50:956-957

[51] Ware WH, Campbell JC, Taylor RC. Effect of a steroid on postoperative swelling and trismus. Dental Progress. 1963;3:116-120

[52] Nathanson NR, Seifert DM. Betamethasone in dentistry. A clinical report. Oral Surgery, Oral Medicine, Oral Pathology and Oral Radiology. 1964;18:715-721

[53] Hooley JR, Francis FH. Betamethasone in traumatic oral surgery. Journal of Oral Surgery. 1969;27:398-403

[54] Messer EJ, Keller JJ. The use of intraoral dexamethasone after extraction of mandibular third molars. Oral Surgery, Oral Medicine, and Oral Pathology. 1975;40:594-598

[55] Caci F, Gluck GM. Double-blind study of prednisolone and papase as inhibitors of complications after oral surgery. Journal of the American Dental Association (Chicago, IL). 1976;93:325-328

[56] Huffman GG. Use of methylprednisolone sodium succinate to reduce post-operative edema after removal of impacted third molars. Journal of Oral Surgery. 1977;35:198-199

[57] Edilby GI, Canniff JP, Harris M. A double-blind placebo-controlled trial of the effect of dexamethasone on postoperative swelling. Journal of Dental Research. 1982;61:556

[58] Skjelbred P, Løkken P. Post-operative pain and inflammatory reaction reduced by injection of a corticosteroid: A controlled trial in bilateral oral surgery. European Journal of Clinical Pharmacology. 1982;21:391-396

[59] Skjelbred P, Løkken P. Reduction of pain and swelling by a corticosteroid injected 3 hours after surgery. European Journal of Clinical Pharmacology. 1982;23:141-146

[60] Skjelbred P, Lokken P. Effects of naloxone on post-operative pain and steroid-induced analgesia. British Journal of Clinical Pharmacology. 1983;15:221-226

[61] Bystedt H, Nordenram A. Effect of methylprednisolone on complications after removal of impacted mandibular third molars. Swedish Dental Journal. 1985;9:65-69 
[62] ElHag M, Coghlan K, Christmas P, Harvey W, Harris M. The anti-inflammatory effects of dexamethasone and therapeutic ultrasound in oral surgery. The British Journal of Oral \& Maxillofacial Surgery. 1985;23:17-23

[63] Pederson A. Decadronphosphate in the relief of complaints after third molar surgery. International Journal of Oral and Maxillofacial Surgery. 1985;14:235-240

[64] Sisk A, Bonnington GJ. Evaluation of methylprednisolone and flurbiprofen for inhibition of postoperative inflammatory response. Oral Surgery, Oral Medicine, and Oral Pathology. 1985;60:137-145

[65] Beirne OR, Hollander BH. The effect of methylprednisolone on pain trismus and swelling after removal of third molars. Oral Surgery, Oral Medicine, and Oral Pathology. 1986;61: 134-138

[66] Olstad OA, Skjelbred P. Comparison of the analgesic effect of a corticosteroid and paracetamol in patients with pain after oral surgery. British Journal of Clinical Pharmacology. 1986;22:437-442

[67] Holland CS. The influence of methylprednisolone on post-operative swelling following oral surgery. The British Journal of Oral \& Maxillofacial Surgery. 1987;25:293-299

[68] Troullos ES, Hargreaves KM, Butler DP, Dionne RA. Comparison of nonsteroidal antiinflammatory drugs, ibuprofen and flurbiprofen, with methylprednisolone and placebo for acute pain, swelling, and trismus. Journal of Oral and Maxillofacial Surgery. 1990;48: 945-952

[69] Neupert EA, Lee JW, Philput CB, Gordon JR. Evaluation of dexamethasone for reduction of postsurgical sequelae of third molar removal. Journal of Oral and Maxillofacial Surgery. 1992;50:1177-1182

[70] Baxendale BR, Vater M, Lavery KM. Dexamethasone reduces pain and swelling following extraction of third molar teeth. Anesthesia. 1993;48:961-964

[71] Hyrkäs T, Ylipaavalniemi P, Oikarinen VJ, Paakkari I. A comparison of diclofenac with and without single-dose intravenous steroid to prevent postoperative pain after third molar removal. Journal of Oral and Maxillofacial Surgery. 1993;51:634-636

[72] Milles M, Desjardins PJ. Reduction of postoperative facial swelling by low-dose methylprednisolone: An experimental study. Journal of Oral and Maxillofacial Surgery. 1993;51: 987-991

[73] Schmelzeisen R, Frölich JC. Prevention of postoperative swelling and pain by dexamethasone after operative removal of impacted third molar teeth. European Journal of Clinical Pharmacology. 1993;44:275-277

[74] Schultze-Mosgau S, Schmelseizen R, Frölich JC, Schmele H. Use of ibuprofen and methylprednisolone for the prevention of pain and swelling after removal of impacted third molars. Journal of Oral and Maxillofacial Surgery. 1995;53:2-7 
[75] Esen E, Tasar F, Akhan O. Determination of the antiinflammatory effects of methylprednisolone on the sequelae of third molar surgery. Journal of Oral and Maxillofacial Surgery. 1999;57:1201-1206

[76] Dionne RA, Gordon SM, Rowan J, Kent A, Brahim JS. Dexamethasone suppresses peripheral prostanoid levels without analgesia in a clinical model of acute inflammation. Journal of Oral and Maxillofacial Surgery. 2003;61:997-1003

[77] Ustün Y, Erdogan O, Esen E, Karsli ED. Comparison of the effects of 2 doses of methylprednisolone on pain, swelling, and trismus after third molar surgery. Oral Surgery, Oral Medicine, Oral Pathology, Oral Radiology, and Endodontics. 2003;96:535-539. DOI: 10.1016/s1079210403004645

[78] Bamgbose BO, Akinwande JA, Adeyomo WL, Ladeinde AL, Arotiba GT, Ogunlewe MO. Effects of co-administered dexamethasone and diclofenac potassium on pain, swelling and trismus following third molar surgery. Head \& Face Medicine. 2005;7:1-11. DOI: 10.1186/1746-160X-1-11

[79] López-Carriches C, Martínez-González JM, Donado-Rodríguez M. Analgesic efficacy of diclofenac versus methylprednisolone in the control of postoperative pain after surgical removal of lower third molars. Medicina Oral, Patología Oral y Cirugía Bucal. 2005;10:432-439

[80] Moore PA, Brar P, Smiga ER, Costello BJ. Preemptive rofecoxib and dexamethasone for prevention of pain and trismus following third molar surgery. Oral Surgery, Oral Medicine, Oral Pathology, Oral Radiology, and Endodontics. 2005;99:1-7. DOI: 10.1016/j. tripleo.2004.08.028

[81] Tiwana PS, Foy SP, Shugars DA, Marciani RD, Conrad SM, Phillips C, White RP. The impact of intravenous corticosteroids with third molar surgery in patients at high risk for delayed health-related quality of life and clinical recovery. Journal of Oral and Maxillofacial Surgery. 2005;63:55-62

[82] Buyukkurt MC, Gungormus M, Kaya O. The effect of a single dose prednisolone with and without diclofenac on pain, trismus, and swelling after removal of mandibular third molars. Journal of Oral and Maxillofacial Surgery. 2006;64:1761-1766. DOI: 10.1016/j. joms.2005.11.107

[83] Graziani F, D’Aiuto F, Arduino PG, Tonelli M, Gabriele M. Perioperative dexamethasone reduces post-surgical sequelae of wisdom tooth removal. A split-mouth randomized double-masked clinical trial. International Journal of Oral and Maxillofacial Surgery. 2006;35:241-246. DOI: 10.1016/j.joms.2005.07.010

[84] López-Carriches C, Martínez-González JM, Donado-Rodríguez M. The use of methylprednisolone versus diclofenac in the treatment of inflammation and trismus after surgical removal of lower third molars. Medicina Oral, Patología Oral y Cirugía Bucal. 2006;11:E440-E445 
[85] Micó-Llorens JM, Satorres-Nieto M, Gargallo-Albiol J, Arnabat-Domínquez J, BeriniAytés L, Gay-Escoda C. Efficacy of methylprednisolone in controlling complications after impacted lower third molar surgical extraction. European Journal of Clinical Pharmacology. 2006;62:693-698. DOI: 10.1007/s00228-006-0164-5

[86] Ordulu M, Aktas I, Yalcin S, Azak AN, Evlioglu G, Disci R, Emes Y. Comparative study of the effect of tube drainage versus methylprednisolone after third molar surgery. Oral Surgery, Oral Medicine, Oral Pathology, Oral Radiology, and Endodontics. 2006;101:e96e100. DOI: 10.1016/j.tripleo.2005.09.002

[87] Grossi GB, Maiorana C, Garramone RA, Borgonovo A, Beretta M, Farronato D, Santoro F. Effect of submucosal injection of dexamethasone on postoperative discomfort after third molar surgery: A prospective study. Journal of Oral and Maxillofacial Surgery. 2007; 65:2218-2226. DOI: 10.1016/j.joms.2006.11.036

[88] Filho JRL, Maurette PE, Allais M, Cotinho M, Fernandes C. Clinical comparative study of the effectiveness of two dosages of dexamethasone to control post-operative swelling, trismus and pain after the surgical extraction of mandibular impacted third molars. Medicina Oral, Patología Oral y Cirugía Bucal. 2008;13:E129-E132

[89] Zandi M. Comparison of corticosteroids and rubber drain for reduction of sequelae after third molar surgery. Oral and Maxillofacial Surgery. 2008;12:29-33. DOI: 10.1007/ s10006-008-0096-6

[90] Vegas-Bustamante E, Micó-Llorens J, Gargallo-Albiol J, Satorres-Nieto M, Berini-Aytes L, Gay-Escoda C. Efficacy of methylprednisolone injected into the masseter muscle following the surgical extraction of impacted lower third molars. International Journal of Oral and Maxillofacial Surgery. 2008;37:260-263. DOI: 10.1016/j/ijom.2007.07.018

[91] Chopra D, Rehan HS, Mehra P, Kakkar AK. A randomized, double-blind, placebo-controlled study comparing the efficacy and safety of paracetamol, serratiopeptidase, ibuprofen and betamethasone using the dental impaction pain model. International Journal of Oral and Maxillofacial Surgery. 2009;38:350-355. DOI: 10.1016/j.ijom.2008.12.013

[92] Gataa IS, Nemat AH. Evaluation of the effectiveness of two methods using methylprednisolone on post-operative sequelae following lower third molar surgery. Kufa Medical Journal. 2009;12:257-266

[93] Tiigimae-Saar J, Leibur E, Tamme T. The effect of prednisolone on reduction of complaints after impacted third molar removal. Stomatologija. 2010;12:17-22

[94] Kang S-H, Choi Y-S, Byun I-Y, Kim M-K. Effect of preoperative prednisolone on clinical post-operative symptoms after surgical extractions of mandibular third molars. Australian Dental Journal. 2010;55:462-467. DOI: 10.111/j.1834-7819.2010.01271.x

[95] Majid OW, Mahmood WK. Effect of submucosal and intramuscular dexamethasone on post-operative sequelae after third molar surgery: Comparative study. The British Journal of Oral \& Maxillofacial Surgery. 2011;49:647-652. DOI: 10.1016/j.bjoms.2010.09.021 
[96] Majid OW. Submucosal dexamethasone injection improves quality of life measures after third molar surgery: A comparative study. Journal of Oral and Maxillofacial Surgery. 2011;69:2289-2297. DOI: 10.1016/j.joms.2011.01.037

[97] Deo SP, Shetty P. Effect of submucosal injection of dexamethasone on post-operative sequelae of third molar surgery. Journal of Nepal Medical Association. 2011;51:71-77

[98] Antunes AA, Avelar RL, Neto ECM, Frota R, Dias E. Effect of two routes of administration of dexamethasone on pain, edema, and trismus in impacted lower third molar surgery. Oral and Maxillofacial Surgery. 2011;15:217-223. DOI: 10.1007/s10006-011-0290-9

[99] Kaur J, Sandhu S, Kaur T, Bhullar RS, Sandhu Y, Singh P. Effect of methylprednisolone on postoperative pain, swelling and trismus following the surgical removal of bilateral impacted mandibular third molars. IJCDC. 2011;1:36-42

[100] Mushtaq M, Khan AH, Hussain A. Effect of dexamethasone on swelling, pain and trismus following third molar surgery. Gomal Journal of Medical Sciences. 2011;9:74-77

[101] Boonsiriseth K, Klongnoi B, Sirintawat N, Saengsirinavin C, Wongsirichat N. Comparative study of the effect of dexamethasone injection and consumption in lower third molar surgery. International Journal of Oral and Maxillofacial Surgery. 2012;41:244-247. DOI: 10.1016/j.ijom.2011.12.011

[102] Klongnoi B, Kaewpradub P, Boonsiriseth K, Wongsirichat N. Effect of single dose preoperative intramuscular dexamethasone injection on lower impacted third molar surgery. International Journal of Oral and Maxillofacial Surgery. 2012;41:376-379. DOI: 10.1016/j.ijom.2011.12.014

[103] Loganathan S, Srinivasan H. A comparative evaluation of methylprednisolone and dexamethasone injection into the masseter muscle in surgical removal of impacted lower third molars. International Journal of Current Research and Review. 2012;4:133-136

[104] Murugesan K, Sreekumar K, Sabapathy B. Comparison of the roles of serratiopeptidase and dexamethasone in the control of inflammation and trismus following impacted third molar surgery. Indian Journal of Dental Research. 2012;23:709-713

[105] Panwar SK. The role of oral prednisolone on swelling, trismus and pain after removal of impacted mandibular third molar. JMST. 2012;1:44-52

[106] Acham S, Klampfl A, Truschnegg A, Kirmeier R, Sandner-Kiesling A, Jakse N. Beneficial effect of methylprednisolone after mandibular third molar surgery: A randomized, double-blind, placebo-controlled split-mouth trial. Clinical Oral Investigations. 2013;17:1693-1700. DOI: 10.1007/s00784-012-0867-1

[107] Arakeri G, Raj KK, Shivakumar HR, Jayade B. A randomized clinical trial to compare efficacy of submucosal aprotinin injection and intravenous dexamethasone in reducing pain and swelling after third molar surgery: A prospective study. Journal of Maxillofacial and Oral Surgery. 2013;12:73-79 
[108] Bauer HC, Duarte FL, Horliana AC, Torta-mano IP, Perez FE, Simone JL, Jorge WA. Assessment of preemptive analgesia with ibuprofen coadministered or not with dexamethasone in third molar surgery: A randomized double-blind controlled clinical trial. Oral and Maxillofacial Surgery. 2013;17:165-171. DOI: 10.1007/s10006-012-0360-7

[109] Bortoluzzi MC, Capella DL, Barbieri T, Plagiarini M, Cavalier T, Manfro R. A single dose of amoxicillin and dexamethasone for prevention of post-operative complications in third molar surgery: A randomized, double-blind, placebo controlled clinical trial. Journal of Clinical Medicine Research. 2013;5:26-33. DOI: 10.4021/jocmr1160w

[110] Channar KA, Kumar N, Ul Hassan Q, Memon AB. Dexamethasone in control of postoperative sequelae after extraction of mandibular impacted third molars. Medical Channel. 2013;19:63-66

[111] Chaurand-Lara J, JA F-U. Methylprednisolone injection following the surgical extraction of impacted lower third molars: A split-mouth study. Open Journal of Stomatology. 2013;3:192-196. DOI: 10.4236/ojst.2013.32033

[112] Christensen J, Matzen LH, Vaeth M, Wenzel A, Schou S. Efficiency of bupivacaine versus lidocaine and methylprednisolone versus placebo to reduce postoperative pain and swelling after surgical removal of mandibular third molars: A randomized, doubleblinded, crossover clinical trial. Journal of Oral and Maxillofacial Surgery. 2013;71:14901499. DOI: 10.1016/j.joms.2013.05.001

[113] Flores RJM, Aguilar OSH, Ochoa ZMG. Betamethasone (sodium phosphate + acetate) prevents inflammation and trismus in retained lower third-molar surgery. Glucocorticoids in third-molar surgery. Revista ADM. 2013;70:190-196

[114] Majid OW, Mahmood WK. Use of dexamethasone to minimise post-operative sequelae after third molar surgery: Comparison of five different routes of administration. Oral Surgery. 2013;6:200-208. DOI: 10.1111/ors.12049

[115] Mehra P, Reebye U, Nadershah M, Cottrell D. Efficacy of anti-inflammatory drugs in third molar surgery: A randomized clinical trial. International Journal of Oral and Maxillofacial Surgery. 2013;42:835-842. DOI: 10.1016/j/ijom.2013.02.017

[116] Nair RB, Rahman NMM, Ummar M, Hafiz KAA, Isaac JK, Sameer KM. Effect of submucosal injection of dexamethasone on post-operative discomfort after third molar surgery: A prospective study. The Journal of Contemporary Dental Practice. 2013;14:401-404

[117] Warraich R, Faisal M, Rana M, Shaheen A, Gellrich N-C, Rana M. Evaluation of postoperative discomfort following third molar surgery using submucosal dexamethasoneA randomized observer blind prospective study. Oral Surgery, Oral Medicine, Oral Pathology, Oral Radiology. 2013;116:16-22. DOI: 10.1016/j.oooo.2012.12.007

[118] Agostinho CN, da Silva VC, Maia Filho EM, Cruz ML, Bastos EG. The efficacy of 2 different doses of dexamethasone to control post-operative swelling, trismus and pain after third molar extractions. General Dentistry 2014;62:e1-e5. 
[119] Ehsan A, Bukhairi SGA, Ashar AM, Junaid M. Effects of pre-operative submucosal dexamethasone injection on the post-operative swelling and trismus following surgical extraction of mandibular third molar. Journal of the College of Physicians and SurgeonsPakistan. 2014;24:489-492

[120] Kaur N, Misurya R, Narula R, Kumar M, Neelkamal N. Comparison of the clinical efficacy of methylprednisolone with ibuprofen and ibuprofen alone on the postoperative sequelae of surgical removal of impacted third molar. Indian Journal of Pain. 2014;28:105-110

[121] Marques J, Pié-Sánchez J, Figueiredo R, Valmaseda-Castellón E, Gay-Escoda C. Effect of the local administration of betamethasone on pain, swelling and trismus after impacted lower third molar extraction. A randomized, tripleblinded, controlled trial. Medicina Oral, Patología Oral y Cirugía Bucal. 2014;19:e49-e54. DOI: 10.4317/medoral.19280

[122] Noboa MM, Ramacciato JC, Teixeira RG, Vicentini CB, Groppo FC, Lopes Motta RH. Evaluation of effects of two dexamethasone formulations in impacted third molar surgeries. Rev Dor São Paulo. 2014;15:163-168. DOI: 10.5935/1806-0013.20140036

[123] Shaikh MI, Khatoon S, Rajput F, Shah SYA. Impacted mandibular third molar surgery; the role of dexamethasone in postoperative swelling and trismus. Professional Medizinhistorisches Journal. 2014;21:1272-1278

[124] Ashraf J, Yaqoob A, Yaqoob G, Ahad M, Rasheed N, Yaqoob M. Evaluation and comparison of locally infiltrated methylprednisolone and intramuscularly injected methylprednisolone in controlling the post-operative sequelae of impacted mandibular third molar extraction-In vivo study. IJRID. 2014;4:98-116

[125] Koçer G, Yuce E, Tuzuner Oncul A, Dereci O, Koskan O. Effect of the route of administration of methylprednisolone on edema and trismus in impacted lower third molar surgery. International Journal of Oral and Maxillofacial Surgery. 2014;43:639-643. DOI: 10.1016/j.ijom.2013.11.005

[126] Selvaraj L, Rao SH, Lankupalli AS. Comparison of efficacy of methylprednisolone injection into masseter muscle versus gluteal muscle for surgical removal of impacted lower third molar. Journal of Maxillofacial and Oral Surgery. 2014;13:495-498. DOI: 10.1007/ s12663-013-0562-z

[127] Vyas N, Agarwal S, Shah N, Patel D, Aapaliya P. Effect of single dose intramuscular methylprednisolone injection into the masseter muscle on the surgical extraction of impacted lower third molars: A randomized controlled trial. Kathmandu University Medical Journal. 2014;12:4-8

[128] Alcântara CEP, Faici SGM, Oliveria-Ferreira F, Santos CRR, Pinheiro MLP. Pre-emptive effect of dexamethasone and methylprednisolone on pain, swelling, and trismus after third molar surgery: A split-mouth randomized triple-blind clinical trial. International Journal of Oral and Maxillofacial Surgery. 2014;43:93-98. DOI: 10.1016/j.ijom.2013.05.016 
[129] Darwade DA, Kumar S, Mehta R, Sharma AR, Reddy GS. Search of a better option: Dexamethasone versus methylprednisolone in third molar impaction surgery. Journal of International Oral Health. 2014;6:14-17

[130] Chappi DM, Suresh KV, Patil MR, Desai R, Tauro DP, Shiva Bharani KNS, Parkar MI, Babaji HV. Comparison of clinical efficacy of methylprednisolone and serratiopeptidase for reduction of postoperative sequelae after lower third molar surgery. Journal of Clinical and Experimental Dentistry. 2015;7:e197-e202. DOI: 10.4317/jced.51868

[131] Chaudhary PD, Rastogi S, Gupta P, Niranjanaprasad Indra B, Thomas R, Choudhury R. Pre-emptive effect of dexamethasone injection and consumption on post-operative swelling, pain and trismus after third molar surgery. A prospective, double blind and randomized study. Journal of Oral Biology and Craniofacial Research. 2015;5:21-27. DOI: 10.1016/j.jobcr.2015.02.001

[132] Gopalakrishnan V, Darekar HS, Sahoo NK. Effectiveness of submucosal v/s intramuscular dexamethasone in mandibular third molar surgeries. IJMSCI. 2015;2:648-655

[133] Sabhlok S, Kenjale P, Mony D, Khatri I, Kumar P. Randomized controlled trial to evaluate the efficacy of oral dexamethasone and intramuscular dexamethasone in mandibular third molar surgeries. Journal of Clinical and Diagnostic Research. 2015;9:ZC48-ZC51. DOI: $10.7860 / J C D R / 2015 / 13930.6813$

[134] Zerener T, Aydintug YS, Sencimen M, Bayar GR, Yazici M, Altug HA, Misir AF, Acikel C. Clinical comparison of submucosal injection of dexamethasone and triamcinolone acetonide on post-operative discomfort after third molar surgery. Quintessence International. 2015;46:317-326. DOI: 10.3290/j.qi.a33281

[135] Dereci O, Tuzuner-Oncul AM, Kocer G, Yuce E, Askar M, Ozturk A. Efficacy of immediate postoperative intramasseteric dexamethasone injection on postoperative swelling after mandibular impacted third molar surgery: A preliminary split-mouth study. The Journal of the Pakistan Medical Association. 2016;66:320-323

[136] Paiva-Oliveira JG, Bastos PR, Cury Pontes ER, da Silva JC, Delgado JA, Oshiro-Filho NT. Comparison of the anti-inflammatory effect of dexamethasone and ketorolac in the extractions of third molars. Oral and Maxillofacial Surgery. 2016;20:123-133. DOI: 10.1007/s10006-015-0533-2

[137] Quadri A, Imran M, Quadri S. Comparative clinical evaluation of submucosal and intramuscular dexamethasone in reducing post operative sequelae following impacted mandibular third molar surgery. IJSS Journal of Surgery. 2016;2:84-87. DOI: 10.17354/ SUR/2016/61

[138] Saravanan K, Kannan R, John RR, Nantha Kumar C. A single pre operative dose of sub mucosal dexamethasone is effective in improving post operative quality of life in the surgical management of impacted third molars: A comparative randomised prospective study. Journal of Maxillofacial and Oral Surgery. 2016;15:67-71. DOI: 10.1007/ s12663-015-0795-0 
[139] Al-Dajani M. Can preoperative intramuscular single-dose dexamethasone improve patient-centered outcomes following third molar surgery? Journal of Oral and Maxillofacial Surgery. 2017;75:1616-1626. DOI: 10.1016/j.joms.2017.03.037

[140] Al-Shamiri HM, Shawky M, Hassanein N. Comparative assessment of preoperative versus postoperative dexamethasone on postoperative complications following lower third molar surgical extraction. International Journal of Dentistry. 2017;2017:1350375. DOI: $10.1155 / 2017 / 1350375$

[141] Barbalho JC, Vasconcellos RJ, de Morais HH, Santos LA, Almeida RA, Rêbelo HL, Lucena EE, de Araújo SQ. Effects of co-administered dexamethasone and nimesulide on pain, swelling, and trismus following third molar surgery: A randomized, triple-blind, controlled trial. International Journal of Oral and Maxillofacial Surgery. 2017;46:236-242. DOI: 10.1016/j.ijom.2016.10.011

[142] Chugh A, Singh S, Mittal Y, Chugh V. Submucosal injection of dexamethasone and methylprednisolone for the control of postoperative sequalae after third molar surgery: Randomized controlled trial. International Journal of Oral and Maxillofacial Surgery. 2017. DOI: 10.1016/j.ijom.2017.07.009.

[143] Gozali P, Boonsiriseth K, Kiattavornchareon S, Khanijou M, Wongsirichat N. Decreased post-operative pain using sublingual injection of dexamethasone $(8 \mathrm{mg})$ in lower third molar surgery. Journal of Dental Anesthesia and Pain Medicine. 2017 Mar;17:47-53. DOI: 10.17245/jdapm.2017.17.1.47

[144] Khalida B, Fazal M, Muntaha ST, Khan K. Effect of submucosal injection of dexamethasone on post-operative swelling and trismus following impacted mandibular third molar surgery. Pakistan Oral \& Dental Journal. 2017;37:231-234

[145] Lim D, Ngeow WC. A comparative study on the efficacy of submucosal injection of dexamethasone versus methylprednisolone in reducing postoperative sequelae after third molar surgery. Journal of Oral and Maxillofacial Surgery. 2017;75:2278-2286. DOI: 10.1016/j.joms.2017.05.033

[146] Lima CAA, Favarinj VT, Torres AM, da Silva RA, Sato FRL. Oral dexamethasone decreases postoperative pain, swelling, and trismus more than diclofenac following third molar removal: A randomized controlled clinical trial. Oral and Maxillofacial Surgery. DOI: $10.1007 / \mathrm{s} 10006-017-0635-0$

[147] Lima TC, Bagordakis E, Falci SGM, Dos Santos CRR, Pinheiro MLP. Pre-Emptive effect of dexamethasone and diclofenac sodium associated with codeine on pain, wwelling, and trismus after third molar surgery: A split-mouth, randomized, triple-blind, controlled clinical trial. Journal of Oral and Maxillofacial Surgery. DOI: 10.1016/j.joms.2017.06.012

[148] Mojsa IM, Pokrowiecki R, Lipczynski K, Czerwonka D, Szczeklik K, Zaleska M. Effect of submucosal dexamethasone injection on postoperative pain, oedema, and trismus following mandibular third molar surgery: A prospective, randomized, double-blind clinical trial. International Journal of Oral and Maxillofacial Surgery. 2017;46:524-530. DOI: 10.1016/j.ijom.2016.11.006 
[149] Rocha-Neto AM, Nogueira EF, Borba PM, Laureano-Filho JR, Vasconcelos BC. Application of dexamethasone in the masseter muscle during the surgical removal of lower third molars. The Journal of Craniofacial Surgery. 2017;28:e43-e47. DOI: 10.1097/SCS.00 00000000003188 .

[150] Selimović E, Ibrahimagić-Šeper L, Šišić I, Sivić S, Huseinagić S. Prevention of trismus with different pharmacological therapies after surgical extraction of impacted mandibular third molar. Medicinski Glasnik (Zenica). 2017;14:145-151. DOI: 10.17392/871-16

[151] Syed KB, AlQahtani FH, Mohammad AH, Abdullah IM, Qahtani HS, Hameed MS. Assessment of pain, swelling and trismus following impacted third molar surgery using injection dexamethasone submucosally: A prospective, randomized, crossover clinical study. Journal of International Oral Health. 2017;9:116-121. DOI: 10.4103/jioh.jioh_65_17

[152] Yeoman CM, Greenspan JS, Harding SM. Recurrent oral ulceration. A double-blind comparison of treatment with betamethasone valerate aerosol and placebo. British Dental Journal. 1978;144:114-116

[153] Pimlott SJ, Walker DM. A controlled clinical trial of the efficacy of topically applied fluocinonide in the treatment of recurrent aphthous ulceration. British Dental Journal. 1983;154:174-177

[154] Lo Muzio L, della Valle A, Mignogna MD, Pannone G, Bucci P, Bucci E, Sciubba J. The treatment of oral aphthous ulceration or erosive lichen planus with topical clobetasol propionate in three preparations: A clinical and pilot study on 54 patients. Journal of Oral Pathology \& Medicine. 2001;30:611-617

[155] Rhodus NL, Bereuter J. An evaluation of a chemical cautery agent and an anti-inflammatory ointment for thr treatment of recurrent aphthous stomatitis: A pilot study. Quintessence International. 1998;29:769-773

[156] Teixeira F, Mosqueda-Taylor A, Montano S, Dominguea-Soto L. Treatment of recurrent oral ulcers with mometasone furoate lotion. Postgraduate Medical Journal. 1999;75:574. DOI: $10.1136 /$ pgmj.75.887.574a

[157] Rodriguez M, Rubio JA, Sanchez R. Effectiveness of two oral pastes for the treatment of recurrent aphthous stomatitis. Oral Diseases. 2007;13:490-494. DOI: 10.1111/ j.1601-0825.2006.01327.x

[158] Al-Na'mah ZM, Carson R, Thanoon IAJ. Dexamucobase: A novel treatment for oral aphthous ulceration. Quintessence International. 2009;40:399-404

[159] Fani MM, Ebrahimi H, Pourshahidi S, Aflaki E, Shafiee Sarvestani S. Comparing the effect of phenytoin syrup and triamcinolone acetonide ointment on aphthous ulcers in patients with Bechet's syndrome. Iranian Red Crescent Medical Journal. 2012;14:75-79

[160] Femiano F, Gombos F, Scully C. Recurrent aphthous stomatitis unresponsive to topical corticosteroids: A study of the comparative therapeutic effects of systemic prednisone 
and systemic sulodexide. International Journal of Dermatology. 2003;42:394-397. DOI: 10.1046/j.1365-4362.2003.01853.x

[161] Femiano F, Buonaiuto C, Gombos F, Lanza A, Cirillo N. Pilot study on recurrent aphthous stomatitis (RAS): A randomized placebo-controlled trial for the comparative therapeutic effects of systemic prednisone and systemic montelukast in subjects unresponsive to topical therapy. Oral Surgery, Oral Medicine, Oral Pathology, Oral Radiology, and Endodontics. 2020;109:402-407. DOI: 10.1016/j.tripleo.2009.10.024

[162] Ship JA. Recurrent aphthous stomatitis: An update. Oral Surgery, Oral Medicine, and Oral Pathology. 1996;81:141-147

[163] Belenguer-Guallar I, Jiménez-Soriano Y, Claramunt-Lozano A. Treatment of recurrent aphthous stomatitis. A literature review. Journal of Clinical and Experimental Dentistry. 2014;6:e168-e174. DOI: 10.4317/jced.51401

[164] Brocklehurst P, Tickle M, Glenny AM, Lewis MA, Pemberton MN, Taylor J, Walsh T, Riley P, Yates JM. Systemic interventions for recurrent aphthous stomatitis (mouth ulcers). Cochrane Database of Systematic Reviews. 2012;9:CD005411. DOI: 10.1002/14651858. CD005411.pub2

[165] Holbrook WP, Kristmundsdottir T, Loftsson T. Aqueous hydrocortisone mouthwash solution: Clinical evaluation. Acta Odontologica Scandinavica. 1998;56:157-160

[166] Hegarty MA, Hodgson AT, Lewsey DJ, Porter RS. Fluticasone propionate spray and betamethasone sodium phosphate mouthrinse: A randomized crossover study for the treatment of symptomatic oral lichen planus. Journal of the American Academy of Dermatology. 2002;47:271-279

[167] Cawson RA. Treatment of oral lichen planus with betamethasone. British Medical Journal. 1968;1:86-89

[168] Thongprasom K, Luangjarmekorn L, Sererat T, Taweesap W. Relative efficacy of fluocinolone acetonide compared with triamcinolone acetonide in treatment of oral lichen planus. Journal of Oral Pathology \& Medicine. 1992;21:456-458

[169] Lozada F, Silverman S Jr. Topically applied fluocinonide in an adhesive base in the treatment of oral vesiculoerosive diseases. Archives of Dermatology 1980;116:898-901.

[170] Voute AB, Schulten EA, Langendijk PN, Kostense PJ, van der Waal I. Fluocinonide in an adhesive base for treatment of oral lichen planus. A double-blind, placebo-controlled clinical study. Oral Surgery, Oral Medicine, Oral Pathology, Oral Radiology, and Endodontology. 1993;75:181-185

[171] Carbone M, Conrotto D, Carrozzo M, Broccoletti R, Gandolfo S, Scully C. Topical corticosteroids in association with miconazole and chlorhexidine in the long-term management of atrophic-erosive oral lichen planus: A placebo-controlled and comparative study between clobetasol and fluocinonide. Oral Diseases. 1999;5:44-49 
[172] Lozada-Nur F, Huang MZ, Zhou GA. Open preliminary clinical trial of clobetasol propionate ointment in adhesive paste for treatment of chronic oral vesiculoerosive diseases. Oral Surgery, Oral Medicine, Oral Pathology, Oral Radiology, and Endodontics. 1991;71:283-287

[173] Sardella A, Demarosi F, Oltolina A, Rimondini L, Carrassi A. Efficacy of topical mesalazine compared with clobetasol propionate in treatment of symptomatic oral lichen planus. Oral Diseases. 1998;4:255-259

[174] Gonzalez-Moles MA, Morales P, Rodriguez-Archilla A, Isabel IR, Gonzalez-Moles S. Treatment of severe chronic oral erosive lesions with clobetasol propionate in aqueous solution. Oral Surgery, Oral Medicine, Oral Pathology, Oral Radiology, and Endodontics. 2002;93:264-270

[175] Carbone M, Goss E, Carrozzo M, Castellano S, Conrotto D, Broccoletti R, Gandolfo S. Systemic and topical corticosteroid treatment of oral lichen planus: A comparative study with long-term follow-up. Journal of Oral Pathology \& Medicine. 2003;32:323-329

[176] Lodi G, Scully C, Carrozzo M, Griffiths M, Sugerman PB, Thongprasom K. Current controversies in oral lichen planus: Report of an international consensus meeting. Part 2. Clinical management and malignant transformation. Oral Surgery, Oral Medicine, Oral Pathology, Oral Radiology, and Endodontics. 2005;100:164-178. DOI: 10.1016/j. tripleo.2004.06.077

[177] Eisen D, Carrozzo M, Bagan Sebastian J-V, Thongprasom K. Oral lichen planus: Clinical features and management. Oral Diseases. 2005;11:338-349. DOI: 10.1111/ j.1601-0825.2005.01142.x

[178] Liu C, Xie B, Yang Y, Lin D, Wand C, Lin M, Ge L, Zhou H. Efficacy of intralesional betamethasone for erosive oral lichen planus and evaluation of recurrence: A randomized controlled trial. Oral Surgery, Oral Medicine, Oral Pathology, Oral Radiology. 2013;116:584-590. DOI: 10.1016/j.oooo.2013.07.023

[179] Ryan JG. Pemphigus. A 20-year survey of experience with 70 cases. Archives of Dermatology. 1971;104:14-20

[180] Zhao CY, Murrell DF. Pemphigus vulgaris: An evidence-based treatment update. Drugs. 2015;75:271-284. DOI: 10.1007/s40265-015-0353-6

[181] Cholera M, Chainai-Wu N. Management of pemphigus. Advances in Therapy. 2016;33: 910-958. DOI: 10.1007/s12325-016-0343-4

[182] Knudson RM, Kalaaji AN, Bruce AJ. The management of mucous membrane pemphigoid and pemphigus. Dermatologic Therapy. 2010;23:268-280. DOI: 10.1111/j.1529 $-8019.2010 .01323 . x$

[183] Mentink LF, Mackenzie MW, Toth GG, Laseur M, Lambert FP, Veeger NJ, Cianchini G, Pavlovic MD, Jonkman MF. Randomized controlled trial of adjuvant oral dexamethasone pulse therapy in pemphigus vulgaris. Archives of Dermatology. 2006;142:570-576. DOI: 10.1001/archderm.142.5.570 
[184] Berg T, Bylund N, Marsk E, Jonsson L, Kanerva M, Hultcrantz M, Engström M. The effect of prednisolone on sequelae in Bell's palsy. Archives of Otolaryngology - Head \& Neck Surgery. 2012;138:445-449. DOI: 10.1001/archoto.2012.513

[185] Axelsson S, Berg T, Jonsson L, Engström M, Kanerva M, Stjernquist-Desatnik A. Bell's palsy - The effect of prednisolone and/or valaciclovir versus placebo in relation to baseline severity in a randomised controlled trial. Clinical Otolaryngology. 2012;37:283-290. DOI: $10.1111 / j .1749-4486.2012 .02526 . x$

[186] Murthy JMK, Saxena AB. Bell's palsy: Treatment guidelines. Annals of Indian Academy of Neurology. 2011;14(Suppl 1):S70-S72. DOI: 10.4103/0972-2327.83092

[187] Baugh RF, Basura GJ, Ishii LE, Schwartz SR, Drumheller CM, Burkholder R, Deckard NA, et al. Clinical practice guideline: Bell's palsy. Otolaryngology and Head and Neck Surgery. 2013;149(Suppl 3):S1-S27. DOI: 10.1177/0194599813505967

[188] Minnerop M, Herbst M, Fimmers R, Matz B, Klockgether T. Wüllner. Bell's palsy. Combined treatment of famciclovir and prednisone is superior to prednisone alone. Journal of Neurology. 2008;255:1726-1730. DOI: 10.1007/s00415-008-0008-6

[189] Numthavaj P, Thakkinstian A, Dejthevaporn C, Attia J. Corticosteroid and antiviral therapy for Bell's palsy: A network meta-analysis. BMC Neurology. 2011;11:1. DOI: 10.1186/ 1471-2377-11-1

[190] Al-Hamadani HA, Abdul-Ameer AJ, Abed AN, Hamzah MT. Bell's palsy: Evaluation of clinical response to medical treatment. Iraqi Journal of Medical Sciences. 2013;11:84-88

[191] Madhok VB, Gagyor I, Daly F, Somasundara D, Sullivan M, Gammie F, Sullivan F. Corticosteroids for Bell's palsy (idiopathic facial paralysis). Cochrane Database of Systematic Reviews. 2016;7:CD001942. DOI: 10.1002/14651858.CD001942.pub5

[192] Horten CP. The treatment of arthritic temporomandibular joints by intra-articular injection of hydrocortisone. Oral Surgery. 1953;6:826-829

[193] Kopp S, Wenneberg B, Haraldson T, Carlsson GE. The short-term effect of intra-articular injections of sodium hyaluronate and corticosteroid on temporomandibular joint pain and dysfunction. Journal of Oral and Maxillofacial Surgery. 1985;43:429-435

[194] Kopp S, Akerman S, Nilner M. Short-term effects of intra-articular sodium hyaluronate, glucocorticoid, and saline injections on rheumatoid arthritis. Journal of Craniomandibular Disorders. 1991;5:231-238

[195] Bjørnland T, Gjaerum AA, Møystad A. Osteoarthritis of the temporomandibular joint: An evaluation of the effects and complications of corticosteroid injection compared with injection with sodium hyaluronate. Journal of Oral Rehabilitation. 2007;34:583-589. DOI: 10.1111/j.365-2842.2007.01759.x

[196] Samiee A, Sabzerou D, Edalatpajouh F, Clark GT, Ram S. Temporomandibular joint injection with corticosteroid and local anesthetic for limited mouth opening. Journal of Oral Science. 2011;53:321-325 
[197] Møystad A, Mork-Knutsen BB, Bjørnland T. Injection of sodium hyaluronate compared to a corticosteroid in the treatment of patients with temporomandibular joint osteoarthritis: A CT evaluation. Oral Surgery, Oral Medicine, Oral Pathology, Oral Radiology, and Endodontics. 2008;105:e53-e60. DOI: 10.1016/j.tripleo.2007.08.024

[198] Bouloux GF, Chou J, Krishnan D, Aghaloo T, Kahenasa N, Smith JA, Giannakopoulus $\mathrm{H}$. Is hyaluronic acid or corticosteroid superior to lactated ringer solution in the short term for improving function and quality of life after arthrocentesis? Part 2. Journal of Oral and Maxillofacial Surgery. 2017;75:63-72. DOI: 10.1016/j.joms.2016.08.008

[199] Rogers MJ, Johnson BR, Remeikis NA, BeGole EA. Comparison of effect of intracanal use of ketorolac tromethamine and dexamethasone with oral ibuprofen on post treatment endodontic pain. Journal of Endodontia. 1999;25:381-384. DOI: 10.1016/S00992399(06)81176-3

[200] Negm MM. Intracanal use of a corticosteroid-antibiotic compound for the management of post treatment endodontic pain. Oral Surgery, Oral Medicine, Oral Pathology, Oral Radiology, and Endodontics. 2001;92:435-439. DOI: 10.1067/moe.2001.115975

[201] Ehrmann EH, Messer HH, Adams GG. The relationship of intracanal medicaments to postoperative pain in endodontics. International Endodontic Journal. 2003;36:868-875

[202] Kaufman E, Heling I, Rotstein I, Friedman S, Sion A, Moz C, Stabholtz A. Intraligamentary injection of slow-release methylprednisolone for the prevention of pain after endodontic treatment. Oral Surgery, Oral Medicine, and Oral Pathology. 1994;77:651-654

[203] Stewart GG, Chilton NW. Role of antihistamines and corticosteroids in endodontic practice. Oral Surgery, Oral Medicine, and Oral Pathology. 1958;11:433-440

[204] Stewart G. Combined use of an antibiotic and a corticosteroid for postoperative sequelae in endodontic practice. The Journal of Dental Medicine. 1962;17:142-146

[205] Krasner P, Jackson E. Management of posttreatment endodontic pain with oral dexamethasone: A double-blind study. Oral Surgery, Oral Medicine, and Oral Pathology. 1986;62:187-190

[206] Glassman G, Krasner P, Morse DR, Rankow H, Lang J, Furst ML. A prospective randomized double-blind trial on efficacy of dexamethasone for endodontic interappointment pain in teeth with asymptomatic inflamed pulps. Oral Surgery, Oral Medicine, and Oral Pathology. 1989;67:96-100

[207] Liesinger A, Marshall FJ, Marshall JG. Effect of variable doses of dexamethasone on post treatment endodontic pain. Journal of Endodontia. 1993;19:35-39

[208] Wolfson BC. The role of hydrocortisone in the control of apical periodontitis. Oral Surgery, Oral Medicine, and Oral Pathology. 1954;7:314-321

[209] Thong YL, Messer HH, Siar CH, Saw LH. Periodontal response to two intracanal medicaments in replanted monkey incisors. Dental Traumatology. 2001;17:254-259 
[210] Abbott PV. Medicaments: Aids to success in endodontics. Part 1. A review of literature. Australian Dental Journal. 1990;35:438-448

[211] Kim ST, Abbott PV, McGinley P. The effects of Ledermix paste on discolouration of mature teeth. International Endodontic Journal. 2000;33:227-232

[212] Nobuhara WK, Carnes DL, Giles JA. Anti-inflammatory effects of dexamethasone on periapical tissues following endodontic over-instrumentation. Journal of Endodontia. 1993;19:501-507 
